\title{
Addressing the Problem of Weight Discrimination in Employment
}

\author{
Elizabeth Kristen $\dagger$
}

\section{TABLE OF CONTENTS}

Introduction

I. The Extent and Nature of Weight-Based Employment

Discrimmation

A. Evidence of Discrimination's Existence .....................................62

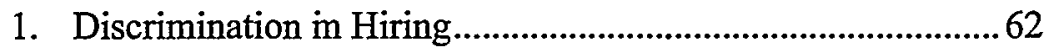

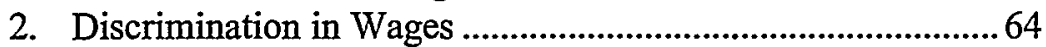

3. Other Forıns of Employment Discrimination ...........................64

B. Explanations for Discrimination-Statistical Discrimination.......66

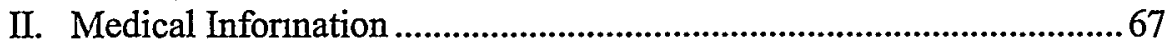

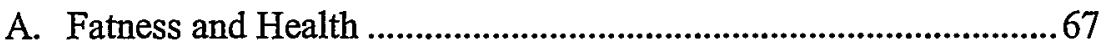

B. The Difficulties and Dangers of Dieting .....................................69

III. Why Antidiscrimination Laws Should Protect Fat People from

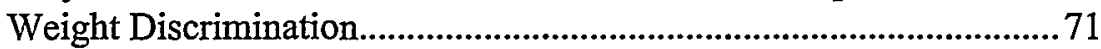

A. The Costs of Antidiscrimination Laws............................................ 71

B. The Benefits of Extending Antidiscrimination Laws to Fat People: Rationales for Extending Legal Protection ...................... 73

1. Why Fat People as a Group Deserve Legal Protection............73

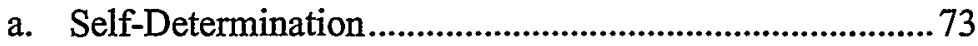

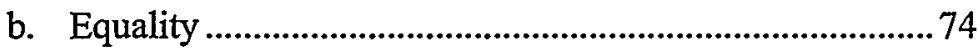

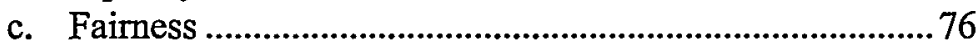

d. Combining Equality and Fairness Concerns .....................77

Copyright (C) 2002 Califomia Law Review, Inc. Califomia Law Review, Inc. (CLR) is a Califomia nonprofit corporation. CLR and the authors are solely responsible for the content of their publications.

$\dagger \quad$ Law Clerk, The Honorable James R. Browning, United States Court of Appeals for the Ninth Circuit; J.D., University of Califomia at Berkeley School of Law (Boalt Hall), 2001; B.A., Miami University, 1988. I would like to thank the members of Califomia Law Review's 2000-01 Notes \& Comments Department, Kate Barry, Ben Beltramo and Jen Polse, for all their encouragentent and support. Thanks too to all the other CLR members who helped prepare this Comment for publication. In addition, this Comment benefited significantly from reviews by Linda Hamilton Krieger and the members of her Advanced Issues in Employment Discrimination Law Seminar, Fall 2000-Spring 2001, especially Dawn Ceizler, Eddie Genna, Christine Reilly, and Cathy Shuck. I would also like to extend my thanks to Hadas Rivera-Weiss, Sondra Solovay, Claudia Center, and Toni Cassista, with whom I had very helpful discussions about this paper. Of course, any errors are mine alone. Fimally, I would like to thank my partner Mali Kigasari and my mother Kathy Braentan, without whom law school would not have been possible. 
e. Practical Difficulties with Combining Equality and Fairness Concerns

2. Why Extending Legal Protection to Fat People Enhances

Rather than Diminishes Antidiscrimination Law

IV. Possible Remedies for Employment Discrimination Against Fat People

A. Antidiscrimination Laws That Protect People with

Disabilities: Bringing Claims Under the Disability or

Perceived Disability Framework.

1. Federal Law: The Americans with Disabilities Act and the Rehabilitation Act of 1973

a. Establishing a Present Impairment ...................................8 83

b. Establishing a Record of an Impairment ............................ 85

c. Establishing a Perceived Disability..................................85

i. Cases Where Courts Sustained Perceived

Disability Claims Brought by Morbidly Obese

Plaintiffs

ii. Cases Where Courts Rejected Perceived

Disability Claims Brought by Morbidly Obese

Plaintiffs

iii. Cases Where Courts Rejected Perceived

Disability Claims Brought by Obese Plaintiffs

iv. Cases Where Courts Upheld Weight

Requirements Despite Disability Discrimination

Arguments

2. State Disability Antidiscrimination Laws..............................93

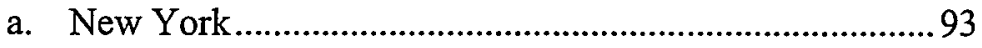

b. New Jersey ................................................................. 94

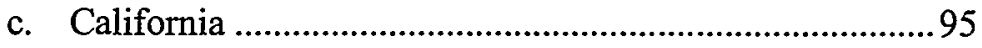

B. Antidiscrimination Laws That Protect Selected Groups:

Bringing Claims Under Disparate Treatment or Disparate Impact Theories.

C. State and Local Ordinances That Prohibit Weight

Discrimination

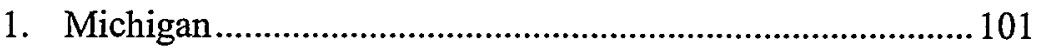

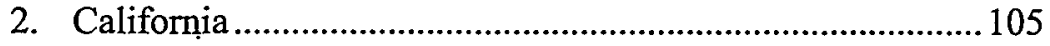

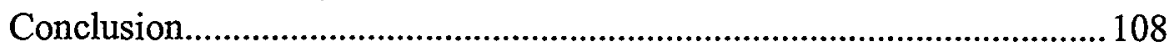




\title{
Addressing the Problem of Weight Discrimination in Employment
}

\author{
Elizabeth Kristen
}

\section{INTRODUCTION}

In 1987, Toni Cassista applied for a job at Community Foods, a health-food store im Santa Cruz, California. ${ }^{1}$ At the time, she was 5 feet 4 inches tall and weighed 305 pounds. When asked, she stated she had no physical limitations that would "interfere with her ability to do the job."2 Despite her qualifications and the fact that she was chosen for a second interview, she was not hired for the position. ${ }^{3}$ When she heard of another vacancy at the store, she applied and again was not selected. ${ }^{4}$ In response to her question about what she could do to improve her chances of getting a job there in the future, the Community Foods personnel coordinator told her that there was concern about her weight. ${ }^{5}$ Ultimately, it seemed, Toni Cassista was not hired simply because she was fat. ${ }^{6}$

1. Cassista v. Community Foods, Inc., 856 P.2d 1143, 1144 (Cal. 1993).

2. Id. at $1144-45$.

3. Id. at 1145 .

4. Id.

5. Id.

6. My use of the word "fat" here may seem surprising. Therefore, before proceeding further, it is important to discuss the variety of terms used to describe people whose weight is deemed greater than it "should" be. Obese, morbidly obese, and overweight are the words used most commonly im legal and medical literature. The term "obese" is a medical term meaning $20 \%$ or more over "ideal" body weight. Jane Byeff Kom, Fat, 77 B.U. L. Rev. 25, 25 n.l (1997). The term "morbid obesity" is used to describe someone who is either one hundred pounds "overweight" or twice their "ideal weight." Carolyn May McDermott, Should Employers Be Allowed to Weigh Obesity in Their Employment Decisions? Cook v. Rhode Island Department of Mental Health, Retardation \& Hospitals, 44 U. KAN. L. REv. 199, 200 (1995). Soine studies define "overweight" by body mass index (BMI). See, e.g., Steven Gortmaker et al., Social and Economic Consequences of Ovenveight in Adolescence and Young Adulthood, 329 NEw ENGL. J. MED. 1008, 1009 (1993). BMI is a number derived by dividing body weight (im kilograms) by height (measured in meters) squared. Richard L. Atkinson, Proposed Standards for Judging the Success of the Treatment of Obesity, 119 ANNALS OF INTERNAL MED. 677, 678 (1993). The Gortmaker study defined overweight as BMI greater than the rinety-fifth percentile of national standards for age and sex. Gortmaker, supra, at 1009. Another study defined overweight as a BMI of 27.8 or more for men and 27.3 or more for woinen. David F. Williamson, Descriptive Epidemiology of Body Weight and Weight Change in U.S. Adults, 119 ANNALS OF INTERNAL MED. 646,646 (1993). These numbers corresponded to $20 \%$ more than "ideal" weight as defined by the Metropolitan Life Insurance Company Tables. Id. "Severely overweight" was defined as 31.1 BMI for men and 32.3 for women. Id. These numbers corresponded to $40 \%$ above "ideal" weight. Id.

While the terms "obese" and "overweight" carry over from the medical literature to the legal world, they may be problematic since they imply "a medicalization of a bodily size, with the meta-message of pathology." Laura S. Brown, Fat-Oppressive Attitudes and the Feminist 
Weight discrimination is a serious problem affecting millions of U.S. workers. ${ }^{7}$ Fat people, and fat women in particular, ${ }^{8}$ experience job-related discrimination in hiring, wages, and the terms and conditions of their employment. ${ }^{9}$ Weight discrimination is both damaging to the U.S. economy and unfair to the affected individuals. ${ }^{10}$ Nevertheless, there is very little legal protection for its victims.

Someone in Toni Cassista's position would have three legal avenues to explore. First, she could pursue an action under federal and state laws that protect people from employment discrimination based on disability or perceived disability. ${ }^{11}$ Second, she could consider whether the weight discrimination she experienced was tied to her sex, race, or some other protected class. ${ }^{12}$ Finally, she could determine whether any state or local law where she lived specifically prohibited weight discrimination in

Therapist: Directions for Change, in Overcoming FeAR of FAT 19, 28 (Laura S. Brown \& Esther D. Rothblum eds., 1989). These terms suggest a foregone acceptance of the conclusion that there are certain ideal body weights and to be above those weights is to be unhealthy. See id:; see also Korn, supra, at $25 \mathrm{n} .1$. Furthermore, since "ideal weight" often is defined by weight tables put forth by insurance companies, it is important to consider bias inherent in these measurements. As one author noted, because these tables "reflect a selected population of mainly white, middle-class Amcricans who buy life insurance, they inay not yield an accurate assessment of other populations." Atkinson, supra, at 677. See also Esther D. Rothbluin, Women and Weight: Fad and Fiction, 124 J. Psychol. 5, 7-8 (1990) (discussing critiques of the insurance weight tables). Therefore, many of the medical terms used to describe weight are loaded with biased assumptions.

By contrast, "fat" is a descriptive term, like tall or short. Brown, supra, at 28. As one activist put it, the word "fat" refers to someone who "weighs over 200 pounds at an 'average' height" or who endures "access problems in public places, job discrimination, random \& frequent attempts at humiliation from strangers (or family \& friends), [or] having to go to special stores or catalogs to find clothes that might fit." Elana Dykewomon, Traveling Fat, in SHadow on a Tightrope: Writings by WoMEN ON Fat Oppression 144, 144-45 (Lisa Schoenfielder \& Barb Wieser eds., 1983) [hereinafter SHADow on A TIGHTROPE1. Because the word "fat" is the one that is preferred by the fat liberation movement, see, e.g., National Association for the Advancement of Fat Acceptance ("NAAFA"), Why Do We Use the Word Fat so Freely?, at http://www.naafa.org/documents/brochures/naafa-info.html\#word (stating that "we find that identifying ourselves as 'fat' is an important step in casting off the shame we have been taught to feel about our bodies"), I use that term throughout the rest of the paper unless one of the other terms is specifically required.

7. By one count, $33 \%$ of people in the US, 58 million adults, have a BMl greatcr than 30 (one definition of overweight). Margaret C. Flynn et al., Syndrome X and the Benefits of Weight Loss, in The Management of Eating Disorders and Obesity 113, 113 (David J. Goldstein ed., 1999). Since $60 \%$ of fat women and $40 \%$ of fat men report employment discrimination, McDermott, supra note 6, at 201, as many as 29 million adults in the US have experienccd weight-based discrimination in the workplace.

8. See infra Part I; see also Scott Petersen, Discrimination Against Ovenveight People: Can Society Still Get Away with It?, 30 GoNz. L. REv. 105, 110 (1994-95).

9. See infra Part 1.

10. See infra Part III.

11. In fact, as will be discussed further in Part IV.A.2.c. infra, Ms. Cassista pursucd a perceived disability claim under Califomia's Fair Employment and Housing Act and lost at the state Supreme Court because of the narrow way in which the court defined perceived disability. Cassista v. Community Foods, Inc., 856 P.2d 1143, 1153-54 (Cal. 1993).

12. Race and sex are protected categories under Title V11. 42 U.S.C. $\$ 2000 \mathrm{e}-2(a)(1)$. See infra Part IV.B. 
employment, since a few jurisdictions have included weight as a protected category in their antidiscrimination laws. ${ }^{13}$

These various approaches have particular strengths and weaknesses. Plaintiffs like Ms. Cassista have had great difficulty succeeding in the courts with disability or perceived disability claims. ${ }^{14}$ Likewise, connecting weight discrimination to an already protected class has not been a particularly effective strategy. ${ }^{15}$ State and local laws explicitly prohibiting weight discrimination provide the most direct protection for fat workers. ${ }^{16}$ Therefore, working toward passage of such laws in more jurisdictions may lead to more effective legal remedies for victims of weight discrimination.

After establishing that fat peoplc do in fact suffer from employment discrimination, this Comment will examine the problems facing fat people in the workplace to assess whether passing local or national weight-based antidiscrimination laws is the best way to provide protection for this group. It also will assess possible legal strategies and discuss recent legislative developments in California that may provide increased protection for the fat population. This Comment concludes that passing local laws to protect people from weight discrimination is the more desirable approach.

Part I considers the empirical and anecdotal evidence demonstrating that fat people experience employment discrimination because of their weight. Part II discusses medical information about weight and health as well as weight loss in order to debunk the myth that being fat is always unhealthy and that weight loss is a viable or desirable outcome. This Part concludes that being fat is effectively immutable. Part III explores the arguments for and against extending the protection of antidiscrimination laws to this particular group and concludes that fat people deserve legal protection from discrimmation. Part IV considers some of the current legal remedies, focusing first on using existing disability discrimination laws to protect fat peoplc from einployment discrimination. This Part also explores the recent changes to California's state disability antidiscrimination law and its potential for providing protection to fat plaintiffs. Further, Part IV discusses the link between discrimination against fat people and other protected groups. Finally, Part IV reviews antidiscrimination laws passed by three jurisdictions that specifically include weight as a protected category. The Comment concludes that recent amendments to California's state disability antidiscrimination laws, as well as San Francisco's ordinance prohibiting weight discrimination, are promising developments and should be extended to other jurisdictions.

13. See infra Part IV.C. Ms. Cassista was involved in the coalition that advocated for the new Santa Cruz law. Sondra Solovay, Tipping the SCales of Justice 233-34 (2000).

14. See infra Part IV.A.I.

15. See infra Part IV.B.

16. See infra Part IV.C. 
I

\section{The Extent and Nature of Weight-Based Employment DISCRIMINATION}

\section{A. Evidence of Discrimination's Existence}

A number of studies, as well as a great deal of anecdotal material, show that fat people are discriminated against in employment. ${ }^{17}$ This discrimination takes many forms, such as failure to hire, payment of lower wages relative to thin or average-weight counterparts, relegation to noncontact positions, and failure to promote. The evidence further suggests that all women, and some women of color in particular, are most affected by weight discrimination. ${ }^{18}$

\section{Discrimination in Hiring}

Fat people are often denied jobs because of their weight. One study showed that almost $16 \%$ of employers would not hire "obese women" at all. ${ }^{19}$ Furthermore, about $44 \%$ of employers said that they would use the fact that a female job candidate was "obese" as "conditional medical

17. See, e.g., Robert C. Klesges et al., The Effect of Applieant's Health Status and Qualifications on Simulated Hiring Decisions, 14 INT'L J. OF OBESITY 527 (1989); Judith Candib Larkin \& Harvey A. Pines, No Fat Persons Need Apply: Experimental Studies of the Overweight Stereotype and Hiring Preferences, 6 Soc. OF WORK AND Occupations 312 (1979); Interview with Deb, in SHADOW ON A TrGHTROPE, supra note 6 at 82 . Other studies demonstrate that fat people are discriminated against in other important areas of life such as education. See Helen Canning \& Jean Mayer, Obesity-Its Possible Effect on College Acceptance, 275 NEw ENG. J. MED. 1172, 1172, 1173 (1966) (studying college acceptance at Ivy League and Seven Sister colleges and concluding that unconscious bias on the part of teachers and college interviewers accounted for the disparity in admission between fat and thin high-school students and that the disparity was particularly great for women); Carey Goldberg, Weight-based Bias More Extensive than Ever Before, S.F. ExAmINER, Nov. 5, 2000, at A3 (discussing a National Education Association position paper that states "fat students experience ostracism, discouragement and sometimes violence" from nursery school through college). See also Gortmaker, supra note 6, at 1010 (following ten thousand people over seven years and finding that those who had been "overweight" initially had completed fewer years of education, had lower household income, greater rates of poverty and lower self-esteem than people who had not been overweight). Some additional studies discuss the effect of "unattractiveness" in various settings such as jury trials, see Cookie Stephan \& Judy Corder Tully, The Influence of Physical Attractiveness of a Plaintiff on the Decisions of Simulated Jurors, 101 J. Soc. PsYCHOL. 149, 150 (1977) (finding that physically attractive plaintiffs were more likely to win their jury trials and that juries awarded them "significantly more money in damages" than unattractive plaintiffs), and receiving help from strangers, David W. Wilson, Helping Behavior and Physical Attractiveness, 104 J. Soc. PsYcHoL. 313 (1978) (finding that people who were physically attractive were more likely to be helped in nonemergency situations, such as asking for directions, than people who were not physically attractive). Neither the Stephan and Tully study nor the Wilson study described how they determined attractiveness. While fat people are not necessarily "unattractive," current U.S. beauty norms glorify being thin. Although some of the studies in this Part date from the 1960s, 1970s, and 1980s, it is unlikely that attitudes about fat people have changed for the better. The negative image of this group has endured.

18. See infra Part IV.B. for a discussion of the link between weight and sex, race, and class.

19. Daphne A. Roe \& Kathleen R. Eickwort, Relationships Between Obesity and Associated Health Factors with Unemployment Among Low Income Women, 31 J. AM. MED. WoMEN's Ass'N 193, 199 (1976). 
grounds for passing over an applicant."20 While these statistics likely reflect overt self-reported bias, the level of discrimination is probably much higher because subtle discrimination is also at work. ${ }^{21}$ In one study, subjects were asked to give their impressions of three potential workers about whoin they were told nothing other than sex and weight.2 ${ }^{22}$ The study participants viewed the overweight candidates as "less competent, less productive, not industrious, disorganized, indecisive, inactive, and less successful. ${ }^{923}$ Similarly, when subjects were shown videotapes of two people, one fat and one thin, taking employee-selection tests and performing almost identically, they rated the fat applicant as a less desirable employee than the thin applicant. ${ }^{24}$

The idea that people make decisions based on physical appearances alone should not be surprising. People are inclined to categorize in order to make choices. ${ }^{25}$ Once we have created or absorbed societal stereotypes, we tend to use these as filters to simplify information processing. ${ }^{26}$ Such stereotypes then infect einployment decision-inaking processes in overt and covert ways. ${ }^{27}$ Even more troubling, such cognitive processes "operate beyond the reach of decision-maker self-awareness." 28 In the studies discussed above, for example, while the participants must have judged the applicants solely on the basis of their weight, they may not have been aware of this bias.

Thus, fat people are at a disadvantage when applying for jobs due to both overt and covert discrimination. What Toni Cassista experienced is not uncommon; one survey found that $60 \%$ of fat women and $40 \%$ of fat men surveyed believed that they had been discriminated against in employment. ${ }^{29}$ As this Comment discusses further in Part III, to the extent that this discrimination unfairly prevents a group of people from full participation in the workplace, such discrimination should be actionable under existing antidiscrimination rubric.

20. Id.

21. See, e.g., Linda H. Krieger, The Content of Our Categories: A Cognitive Bias Approach to Discrimination and Equal Employment Opportunity, 47 STAN. L. REv. 1161, 1187-90 (1995) (arguing that biased employment decisions often result from unconscious categorization rather than conscious aniinus).

22. Larkin \& Pines, supra note 17, at 314 (1979).

23. Id. at 315-16.

24. Id. at 319-21. See also Klesges et al., supra note 17, at 533 (1989) (finding that "overweight" job applicants were viewed as "less likely to get along with others," "lacking in self-control and discipline," and "lonely, depressed, and anxious").

25. See Krieger, supra note 21, at 1163-64.

26. See id. at 1187-88.

27. See id. at 1188.

28. Id.

29. McDermoth, supra note 6, at 201. 


\section{Discrimination in Wages}

In addition to hiring discrimination, fat people face wage discrimination. A recent article discussed a study showing that "fat white women tend to earn significantly less than their thinner counterparts." ${ }^{30}$ It noted that another study found "highly obese" women earn $24 \%$ less than thin women while the so-called moderately obese earn $6 \%$ less. $^{31}$ A Harvard Public Health Study found that fat women have household incomes $\$ 6,710$ lower than thin women..$^{32}$ Fat women also have a $10 \%$ higher rate of poverty..$^{33}$ While fat women are more likely to be poor than their thin counterparts, the authors found no association between weight and socioeconomic variables for men. ${ }^{34}$

\section{Other Forms of Employment Discrimination}

Fat workers are subjected to other less favorable job conditions as well, such as being relegated to "noncontact positions." 35 They are also less likely to be promoted. ${ }^{36}$ Therefore, even when they are able to secure a job, fat workers face discrimination on the job. In addition, fat people often face workplace harassment. This harassment can range from coworkers telling their fat colleague about a new reduction diet to verbal abuse. ${ }^{37}$

In Doe v. City of Belleville, ${ }^{38}$ for example, J. Doe sued his employer in part because his coworkers harassed him about his weight, constantly

30. Goldberg, supra note 17 , at A3.

31. Id.

32. Gortmaker, supra note 6, at 1010 \& 1010 tb1.2.

33. Id. See also Gina Kolata, Women Pay Price for Being Obese, N.Y. Times, Sept. 30, 1993, at A18.

34. Gortmaker, supra note 6 , at 1009 . Interestingly enough, height predicted socioeconomic characteristics for men. A 12 -inch reduction in height was associated with a $10 \%$ increase in poverty rates and a $\$ 3,037$ decline in household income. Id. at 1011. This result may suggest that height as well as weight should be included in antidiscrimination laws as a prohibited basis of discrimination. As this Comment discusses further in Part IV.C., all three jurisdictions that prohibit weight discrimination also ban height discrimination. For a study finding that "overweight" men make $\$ 4,000$ less per year than non-overweight men see Irene H. Frieze et al., Perceived and Actual Discrimination in the Salaries of Male and Female Managers, 20 J. of ApPlied Soc. Psychol. 46, 62 (1990). The Frieze study also confirmed height discrimination in wages for men, finding that for each inch of height, a man's gross annual salary mcreased by $\$ 600$. Id.

35. State of Maryland Commission on Human Relations, Report on the Study of WEIGHT AND S1ZE DisCRIMINAT1ON, Executive Summary (1979).

36. Fatter Executives Get Slimmer Paychecks, InDustry Weex, Jan. 14, 1974, at 21 (cited in Karen M. Kramer \& Arlene B. Mayerson, Obesity Discrimination in the Workplace: Protection Through a Perceived Disability Claim Under the Rehabilitation Act and the Americans with Disabilities Act, 31 CAL. W. L. Rev. 41, 71 (1994)).

37. See Lamoria v. Health Care \& Retirement Corp., 584 N.W.2d 589, 595 n.8 (Mich. Ct. App. 1998), aff'd in relevant part by 593 N.W.2d 699, 701 (Mich. Ct. App. 1999) (suggesting that weight loss advice would not constitute actionable harassment).

38. 119 F.3d 563 (7th Cir. 1997), vacated and remanded by 523 U.S. 1001 (1998) (on issue of same-sex harassment). 
deriding him as "fat boy." Similarly, in Greene v. Seminole Electric Cooperative, Inc. ${ }^{40}$ the plaintiff was subjected to repeated demands to diet, threatened with demotion if he failed to lose weight, and forced to purchase "diet cookies" from his supervisor after the supervisor made fun of his weight. ${ }^{41}$ And in Butterfield v. New York State ${ }^{42}$ the plaintiff, a corrections officer, detailed numerous incidents of weight-related harassment. ${ }^{43}$ The harassment included spraying his locker with cheese, posting a cartoon in the workplace depicting an overweight character (which led to the plaintiff being the target of numerous tasteless jokes), and adding an unknown substance to the plaintiff's open soda causing him nausea and necessitating a trip to the emergency room. ${ }^{44}$ In addition, the plaintiff received harassing phone calls at work and at home in which the caller pretended to vomit, yelled, or banged down the receiver. When the plaintiff had the calls traced, he found they were coming from his workplace. ${ }^{45}$ After he filed a discrimination charge, his mail and time card were tampered with, and he received a dead rat in an envelope.$^{46} \mathrm{He}$ also alleged that he was subjected to derogatory and embarrassing statements such as being called "butterball." 47

These cases provide a few examples of the type of harassment that fat people experience on the job. Such behavior certainly affects the victims' job performance and contributes to the overall difficulty fat people face in the workplace. The harm to the individual is obvious. As subsequent

39. Id. at 566. The court found that $\mathrm{J}$. had an actionable harassment claim not because of the antifat comments, but rather because his coworkers directed sexually abusive comments at him and he witnessed the sexual harassment of his brother. $I d$. at 595-96. The dissenting judge rejected J.'s harassment action, saying that while calling him a "fat boy" was "needlessly cruel and offensive" and violated "normal senses of decency," it was not a Title VII violation and therefore was not actionable. Id. at 601 (Manion, J., dissenting). Since the other conduct was generally not directed at J., the dissent would have rejected J.'s sexual harassment claim altogether. Id. at 601-02 (Manion, J., dissenting).

The Doe case is better known for its holding that the vicious harassment of J. Doe's brother, $H$. Doe (whose coworkers physically assaulted him after relentlessly calling him a "fag" and a "queer") was actionable despite the fact that it was same-sex harassment among heterosexual men. Id. at 566-67. Nevertheless, the coworkers' weight-related harassinent of J. Doe also was at issue in the case.

40. 701 So.2d 646 (Fla. Dist. Ct. App. 1997).

41. Id. at 648. The court allowed the plaintiff to proceed on a hostile work environment claim under the Americans with Disabilities Act and the Rehabilitation Act. Id. at 648 (discussing Florida's disability antidiscrimination law, FLA. STAT. ANN. $\$ \$ 760.10,760.22$ (7)(a) (West 2001)).

42. No. 96 CIV5144(BDP)LMS, 1998 WL 401533, *1 (S.D.N.Y. July 15, 1998).

43. Id. at *1,*4-5.

44. Id. at *4-*5.

45. Id. at $* 5$.

46. Id. at *5-*6.

47. Id. at *6. The court found that the plaintiff presented "graphic evidence" of "an overwhelming and persistent pattern of severe harassment by department personnel," much of which was focused on his weight. Id. at *12. The court further noted management's "striking failure" to investigate or stop the harassment or punish the imdividuals involved. Id. For these reasons, the court allowed the plaintiff to proceed with his claim of perceived disability discrimination under the Americans with Disabilities Act and the Rehabilitation Act. Id. at *13. 
sections argue, weight-based discrimination also hurts the economy and society as a whole. Therefore, courts should follow the lead of Greene and Butterfield and allow workers to proceed in their efforts to hold employers accountable for weight-based workplace harassment.

\section{B. Explanations for Discrimination-Statistical Discrimination}

In order to fully consider whether fat workers should legally be protected from weight discrimination, it is important to review possible reasons for this type of discrimination. Statistical discrimination, a concept developed by economists, is a helpful tool in understanding why discrimination exists. According to this view, employers often utilize stereotypes about particular groups as "cheap proxies" for worker value. ${ }^{48}$ In other words, faced with a decision about which workers will be most productive, employers rely on easily discernable traits (like weight) and the stereotypes associated with those traits to make hiring decisions.

There are a variety of negative stereotypes associated with being fat, including "laziness, low intelligence, gluttony, [and] bad health." stereotypes have real-world implications for job applicants. For example, one woman described her interview for a job as a telephone operator at a phone company. At the interview, the person in charge of hiring asked a number of questions about the applicant's weight and said that the company could not hire fat people because they tended to be sick more often. ${ }^{50}$ Fat people also report not having been hired for positions due to the perception that they were "lazy and undisciplined." In fact, studies even show that people associate being fat with lower intelligence and decreased competence. ${ }^{52}$ Perhaps if such generalizations accurately reflected the truth about this group, employers might be justified in relying on them. However, as with almost all stereotypes, there is little truth to these generalizations about fat people.

The following Part explores two of the most important generalizations about fat: first, that being fat is unhealthy and second, that fat people could lose weight if they tried. These two assumptions in turn tend to support the generalizations that fat people are lazy and undisciplined because they cannot successfully lose weight. Furthermore, viewing fatness as both

48. John J. Donohue III, Employment Discrimination Law in Perspective: Three Concepts of Equality, 92 Mich. L. REv. 2583, 2598 (I994).

49. Evelyn Nieves, New San Francisco Ordinance Decrees That All Sizes Fit, N.Y. Times, May 9, 2000, at A20 (quoting Tom Ammiano). See also Klesges, supra note 17, at 533 (finding that fat applicants were seen as having "poorer work skills," being "less conscientious," "less likely to get along with others," "lacking in self-control and discipline," and "lonely, depressed, and anxious").

50. Interview with Deb, in SHADOW ON A TightROPE, supra note 6, at 88.

51. Cynthia Hubert, San Francisco Says Size Discrimination Must End, ScrIPPs Howard News Service, May 9, 2000, at 2.

52. Judith Rodin, Cultural and Psychosocial Determinants of Weight Concerns, I19 ANNALs of INTERNAL MED. 643, 644 (1993). 
unhealthy and optional leads people to believe that fat people are not making intelligent choices about their lives. This Part concludes that these generalizations are disputed in the medical literature and in fact stem from and reflect unfair bias against fat people.

\section{II MEDICAL INFORMATION \\ A. Fatness and Health}

Despite popular conceptions that being fat is dangerously unhealthy, the picture painted by the medical literature is not so clear. ${ }^{53}$ As two doctors explained im an editorial in the New England Journal of Medicine, both the data linking fat with death and the data showing losmg weight to be healthy are "limited, fragmentary, and often ambiguous." York Times article countered the common perception that all fat people are unhealthy. ${ }^{55}$ It reported on a study that found that when fat people were fit, as defined by aerobic capacity, their death rates were "about the same as lean and flt" people. ${ }^{56}$ Fat people who combined regular exercise with sound eating reduced their risk of diabetes and heart disease even if they did not lose weight. ${ }^{57}$ Another study, which measured fitness by muscle strength, demonstrated that men with the "greatest grip strength" had the "lowest risk of death from all causes" regardless of weight. ${ }^{58}$

53. While there may be "something grotesque about having to quote from medical sources to defend a liberation movement," Vivian F. Mayer, The Fat Illusion, in SHADOw ON A TIGHTROPE, supra note 6 , at 3, 5, the following Part considers the medical literature despite its possible biases in favor of finding fat to be unhealthy. As many authors have pointed out, some medical studies may refiect bias against fat people because of their funding source. Much of the medical information about weight is funded by the $\$ 30$ billion a year diet industry. SolovaY, supra note 13, at 171 (noting Marilyn Wann's statement that money spent on dieting annually could provide "four-year college educations for one third of the country's high school graduates ... [or] provide each of the country's 2.5 million homeless people with two homes of their own"); see also NAAFA, Policy on Obesity Research, at http://naafa.org/documents/policies/obesity_research.html (discussing the leading obesity researchers' potential conflicts of interest). Furthermore, the fact that medical equipment is not designed to accommodate fat people may lead to inaccurate results. See, e.g., NAAFA, Facts About Hypertension and the Fat Person, at http://naafa.org/documents/brochures/hyper/html (suggesting that using the wrong-sized blood pressure cuff can result in an inaccurately high reading); Missouri Commission on Human Rights v. Southwestern Bell Telephone Co., 699 S.W.2d 75, 76 (Mo. Ct. App. 1985) (discussing medical testimony that standard-sized blood pressure cuffs could give "inaccurately high" blood pressure readings when used on "overweight" patients).

54. Jerome P. Kassirer \& Marcia Angell, Losing Weight-An Ill-Fated New Year's Resolution, 338 NEw ENGL. J. MED. 52 (1998), available at http:/www.nejm.org/content/1998/0388/0001/ 0052.asp. Obviously this section does not attempt to provide a detailed review of all the medical literature on weight and health. The purpose of the material cited here is to suggest that there may be another way of viewing the health effects of being fat.

55. Jane Brody, Fat But Fit: A Myth About Obesity Is Slowly Being Debunked, N.Y. Times, Oct. 24,2000 , at D7.

56. Id.

57. Id.

58. Id. 
While fat people may have an increased risk of coronary heart disease, ${ }^{59}$ cardiovascular disease, hypertension, diabetes, gallstones, and certain types of cancer, ${ }^{60}$ they also may have a lower rate of cancer-related deaths. ${ }^{61}$ Even information about whether fat people have an increased risk of coronary heart disease is somewhat contested in the medical literature, ${ }^{62}$ particularly where fat women are concerned, since most studies have focused exclusively on men. ${ }^{63}$

Furthermore, the medical community has not reached a consensus that being fat has uniformly negative health effects. ${ }^{64}$ For example, women who are fat are less likely to suffer from osteoporosis ${ }^{65}$ and have lower rates of premenopausal breast cancer. ${ }^{66}$ Fat people also have lower rates of lung cancer. ${ }^{67}$ Thus, medical information about the dangers of being overweight does not support the view that being fat is necessarily unhealthy. The full picture is more complicated and implicates a number of variables such as fitness and health risk factors, like smoking.

59. JoAnne E. Manson et al., A Prospective Study of Obesity and Risk of Coronary Heart Disease in Women, 332 NEW ENG. J. MED. 882, 882 (1990) ("The influence of obesity on the risk of coronary heart disease remains controversial despite a well-established association between adiposity and unfavorable coronary risk-factor status."). See also David M. Gamer \& Susan C. Wooley, Confronting the Failure of Behavioral and Dietary Treatments for Obesity, 11 CLINICAL PsYCHOL. REv. 729, 753 (1991) (pointing out that while obesity is a "risk factor for cardiovascular disease," such cardiovascular health risks do not necessarily "translate into higher mortality rates").

60. F. Xavier Pi-Sunyer, Medical Hazards of Obesity, 119 ANnals OF InTERnal MEd. 655, 655, 658 (1993) (concluding that overweight men have higher mortality rates for colorectal and prostate cancer and overweight women have increased rates of endometrial, gallbladder, cervical, ovarian and breast cancer). Fat men and women also may be at higher risk for cancer of the esophagus, liver, and pancreas. Jean Paul Deslypere, Obesity and Cancer, 44 Metabolism No. 9, Supp. 3, 24, 24 (1995). Another article suggests that there is insufficient evidence to link being overweight to an increased risk of "colon cancer incidence, morbidity, or mortality." Moske Shike, Body Weight and Colon Cancer, 63 AM. J. Clinical Nutrition 442S, 443S (1996).

61. Stanley M. Garn et al., Fatness \& Mortality in the West of Scotland, 38 AM. J. CliniCaL NutRition 313, 317 (1983) (involving a study of over 2000 men between the ages of 45-75). The authors conclude that "fatness level is ... inversely related to lung cancer and cancer mortality and positively related to cardiovascular mortality." $I d$.

62. Manson, supra note 59, at 882.

63. Id. Nevertheless, this study concludes that "obesity is a strong risk factor for coronary heart disease in middle-aged women." Id. at 888.

64. Garn, supra note 61, at 313 ("As ... suggest[ed] from limited data, there is some evidence that being fat may improve life expectancy rather than the reverse.").

65. Gordon M. Wardlaw, Putting Body Weight and Osteoporosis into Perspective, 63 AM. J. Clinical Nutrition 433S, 433S (1996); Claude Ribot et al., The Effect of Obesity on Postmenopausal Bone Loss and the Risk of Osteoporosis, in ADVANCES IN NUTRITIONAL REs. 257, 259-62 (Harold H. Draper ed., 1994).

66. Rachel Ballard-Barbash \& Christine A. Swanson, Body Weight: Estimation of Risk for Breast and Endometrial Cancers, 63 AM. J. CliniCAl Nutrition 437S, 438S (1996). The authors conclude, however, that when heavier women do develop premenopausal breast cancer, they have decreased survival rates and shorter time periods between recurrences. Id. at $438 \mathrm{~S}$. The study also notes that adult weight gain is associated with a greater risk of postmenopausal breast cancer. Id. at $438 \mathrm{~S}$.

67. Deslypere, supra note 60, at 26. See also Gam, supra note 61 , at 317. 
Even if one believes that being fat is always associated with health risks, it is unjust to discriminate against people in employment on this basis since it is not clear that fat people can do anything about their size. Medical researchers frequently emphasize that weight is influenced by a variety of factors, including genetics. ${ }^{68}$ Furthermore, as discussed below, weight-loss methods are generally unsuccessful.

\section{B. The Difficulties and Dangers of Dicting}

While information about the health risks of being fat does not provide unequivocal support for the proposition that being fat is not unhealthy, the information about weight-loss failure does debunk the myth that fat people are lazy and undisciplined because they cannot lose weight. Dieting is quite prevalent in the U.S., with $40 \%$ of adult women and $20 \%$ of adult men reporting that they were trying to lose weight. ${ }^{69}$ Among high school students, $44 \%$ of females and $15 \%$ of males said they were making efforts to decrease their weight. ${ }^{70}$ In 1990, 53 million dieters spent about $\$ 33$ billion on weight loss programs. ${ }^{71}$ Nevertheless, dieting is remarkably unsuccessful. ${ }^{72}$ As one author noted, people who complete weight loss programs generally lose about $10 \%$ of their body weight but regain most of it within a year. ${ }^{73}$

Although there is increasing agreement in the medical community that weight is influenced by a complicated variety of factors ${ }^{74}$ and that dieting is not effective for most people, ${ }^{75}$ much of the medical literature has ignored the serious health risks associated with many weight loss techniques like

68. Richard L. Atkinson, Etiologies of Obesity, in THE MANagement of EATING Disorders AND OBESITY, supra note 7, at 83, 83 (stating that "[o]ver 100 different genes have been identified that contribute to the etiology of obesity"); Albert J. Stunkard, An Adoption Study of Human Obesity, 314 New ENGL. J. Med. 193 (1986) (discussing a study in which the weight of children adopted by different parents was compared and concluding that "genetic influences are important determinants of body fatness" and that "childhood family environment has little or no effect").

69. Alan S. Levy \& Alan W. Heaton, Weight Control Practices of U.S. Adults Trying to Lose Weight, 119 AnNALs OF INTERNAL MEd. 661, 661 (1993).

70. Mary K. Serdula et al., Weight Control Practices of U.S. Adolescents and Adults, 119 ANNALS OF INTERNAL MED. 667, 668 (1993).

71. NAAFA, Weight Loss: Fact and Fiction, at http://naafa.org/documents/brochures/ weightloss.html.

72. See Thomas A. Wadden, Treatment of Obesity by Moderate and Severe Caloric Restriction, 119 ANNALS OF lNTERNAL MED. 688, 692 (1993) (confirming that "diets don't work" and explaining that short-term "diet and behavior modification is not associated with successful weight control 3 to 5 years later"); see also James O. Hill et al., Obesity Treatment: Can Diet Composition Play a Role?, 119 ANNALS OF INTERNAL MED. 694, 696 (1993) (stating that "'[m]ost obese persons who successfully lose weight regain it within a period of months after the treatment program").

73. Johanna Dwyer, Policy and Healthy Weight, 63 AM. J. Cinical Nutrition 415S, 417S (1996). In fact, repeated diets may actually cause slower weight loss and more rapid weight gain. See Rothblum, supra note 6, at 12 (discussing a study of rats subjected to multiple diets).

74. See supra note 68 and accompanying text.

75. See supra note 73 and accompanying text. 
dieting and surgery (80-90\% of which is performed on women) ${ }^{76}$ For example, dieting has been linked with eating disorders: dieters are eight times more likely to develop such disorders than nondieters. ${ }^{77}$ In addition, studies have found that weight loss and weight fluctuations were associated with risk of death from cardiovascular disease. ${ }^{78}$ The Framingham study, published in the New England Journal of Medicine in 1991, found that a high degree of body-weight variability was "associated with an increased risk of death from all causes, coronary heart disease, and death from coronary heart disease in both men and women." weight, blood pressure, smoking, cholesterol level, and physical activity, "death from all causes, coronary heart disease, and death from coronary heart disease" remained associated with variable weight for men. For women, the association between weight variability and death from all causes, as well as death from coronary heart disease, remained even after considering the factors discussed above. ${ }^{80}$

Furthermore, many of the "cures" for obesity are themselves harmful. For example, "[o]lestra causes a loss of essential nutrients; dexfenfluramine is associated with potentially fatal pulmonary hypertension; and fen-phen may be associated with serious valvular disease of the heart." Weight-loss surgeries have caused "significant health problems and death." $\$ 2$ Moreover, one study posited that fat women have an increased risk of kidney cancer because of diuretic use. ${ }^{83}$

In short, the "cure for obesity may be worse than the condition." 84 The medical information about the health risks of being fat and the

76. Jacklyn Packer, The Role of Stigmatization in Fat People's Avoidance of Physical Exercise, in OVERCOMING FEAR OF FAT, supra note 6, at 49, 56.

77. G. Terrence Wilson, Relation of Dieting and Voluntary Weight Loss to Psychological Functioning and Binge Eating, 119 ANNALS OF INTERNAL MED. 727, 728 (1993).

78. Elsie R. Pamuk et al., Weight Loss and Subsequent Death in a Cohort of U.S. Adults, 119 ANNALS OF INTERNAL MED. 744, 747 (1993) (addressing weight loss); William B. Kannel et al., Effect of Weight on Cardiovascular Disease, 63 AM. J. CuINICAL Nutrution 419S, 419S (1996) (addressing weight fluctuations).

79. Lauren Lissner et al., Variability of Body Weight and Health Outcomes in the Framingham Population, 324 NEW ENGL. J. MED. 1839, 1841 (1991).

80. Id.

81. Kassirer \& Angell, supra note 54, at 52. Dexfenfluramine is a weight loss drug that was marketed under the name of "Redux." U.S. Food and Drug Administration, FDA Announced Withdrawal of Fenfluramine and Dexfenfluramine (Fen-Phen), Sept. 15, 1997, at http://www.fda.gov/cder/news/phen/fenphenpr81597.htm. Fenfluramine is closely related to dexfenfluramine; the FDA determined that both drugs posed an "unacceptable risk" to people taking them. Id. The FDA asked the manufacturers to voluntarily withdraw both of these drugs from the market on September 15, 1997 because of the risk posed to patients. Id. Fen-phen is the term used for a combination of fenfluramine and phentermine. Id. The FDA received numerous reports of cardiac valvular disease among people taking fen-phen. $I d$. The agency did not ask for a withdrawal of phentermine.

82. Rothblum, supra note 6, at 19.

83. Deslypere, supra note 60, at 24.

84. Rothblum, supra note 6, at 19. 
effectiveness of dieting at the very least indicates that there are serious questions about the need for and risks of dieting. Therefore, the prevalent stereotypes about fat workers being lazy and undisciplined because of their failure to permanently lose weight have little support in the medical literature. For purposes of the following analysis, I assume that to be fat is not necessarily unhealthy and that weight is either immutable or so difficult or dangerous to permanently change as to be practically immutable.

\section{III \\ Why Antidiscrimination Laws Should Protect Fat People from WEIGHT DISCRIMINATION}

As discussed above, employers often use physical characteristics such as weight to make hiring decisions. This type of discrimination has a number of troubling effccts. First, it deprives employers of potentially valuable employees. Second, it harms those who do not get the job, both economically and personally. Finally, it can discourage people from investing in their own human capital. ${ }^{85}$ For example, if people who are fat are less likely to derive a real world benefit from higher education, they may be less likely to pursue it. Thus, discrimination can become a vicious cycle in which fat people are unable to secure employment for subjective reasons, are thereby discouraged from investing im their skills, and as a result become less objectively employable. Such results are both inefficient for society as a whole and devastating for the victims of discrimmation.

The effects of discrimination on both individuals and society as a whole are compelling reasons to extend antidiscrimmation laws to cover fat people. ${ }^{86}$ Nevertheless, providing legal protection to any group also entails costs. Therefore, it is important to consider the advantages and disadvantages of extending legal protection against weight-based employment discrimination to fat people.

\section{A. The Costs of Antidiscrimination Laws}

First, antidiscrimination laws impose restraints on individual liberty. One author poses the question: When should government restrict the freedom of some people in order to obtain freedoin for others ${ }^{87}$ Any proposal to extend antidiscrimination laws must consider the balance between "advancing the freedom of the weak by restraining the freedom of the powerful." 8 While some commentators have argued that it is more

85. Donohue, supra note 48 , at 2598.

86. See, e.g., Karol V. Mason, Employment Discrimination Against the Overweight, 15 J. LAw REFORM 337, 346 (1982) (discussing the harm caused to the individual and society).

87. John J. Donohue III, Foundations of Employment Discrimination Law 14 (1997) (citing ISAIAH BERLIN, Four Essays ON LIBERTY 118 (1969)).

88. Id. at 15 (discussing the views of Immanual Kant). 
important to choose liberty over equality when the two concepts are in opposition, ${ }^{89}$ this Comment argues that equality should prevail and employment discrimination laws should be extended to victims of weight discrimination.

A second cost of employment discrimination laws involves real world implementation and enforcement expenses. ${ }^{90} \mathrm{~A}$ third potential cost is to the worker herself. Some economists have argued that providing antidiscrimination protection for workers makes them more expensive to hire because employers fear that they will be sued if they later fire such a protected worker. ${ }^{91}$ For this to be true, the risk of being sued for firing a protected employee would have to be higher than that for failing to hire her in the first place. ${ }^{92}$

Assuming that employment discrimination is costly, the question then becomes what should be done about it. Some economists have argued that to the extent discrimination is inefficient, free-market competition will eliminate it; others have countered that once employers have developed a "taste" for discrimination, they may indulge in that taste despite its cost. ${ }^{93}$ Furthermore, social pressures on employers may cause them to make economically inefficient decisions in order to preserve the status quo and social hierarchy. ${ }^{94}$ If discrimination exists because of market failure, as Professor Donohue suggests, ${ }^{95}$ then the case for government regulation is strong. ${ }^{96}$

89. John J. Donohue III, Discrimination in Employment, in The New Palgrave Dictionary of ECONOMICS \& THE LAW 615, 617 (1998) (discussing the views of Milton Friedman).

90. Richard A. Posner, The Efficiency \& Efficacy of Title VII, I36 U. PA. L. Rev. 513, 514 (1987); John J. Donohue III, Further Thoughts on Employment Discrimination Legislation: A Reply to Judge Posner, I36 U. PA. L. REv. 523, 524, 528-30, 545-46 (1987).

91. Donohue, Discrimination in Employment, supra note 89, at 620 (discussing the views of Richard Epstein).

92. Id. (citing John J. Donohue III \& Peter Siegelman, The Changing Nature of Employment Discrimination Litigation, 43 STAN. L. Rev. 983, 984 (1991)).

93. Id. at 616 (discussing the views of Nobel Prize-winning economist Gary Becker).

94. See id. at 617. Donohue diseusses segregated labor markets in the South in the $1950 \mathrm{~s}$ and 1960 s, saying that "during that era, a Southerner who chose not to discriminate against blacks was deciding to reject an entire social system built on the ideology of white supremacy." While social pressure to discriminate against fat people is not analogous to $1950 \mathrm{~s}-1960$ s system of white supremacy, Donohue makes an important point about the influence of "non-economic" factors in employment decisions.

95. See Donohue, Discrimination in Employment, supra note 89, at 618-19 (explaining that discrimination constitutes a market failure because the market is incapable of performing "seemingly beneficial transactions").

96. Donohue suggests possible government intervention to counter discrimination that falls short of outright antidiscrimination laws. For cxample, he considers a German scheme of tax subsidies for employers who hire disabled workers. Id. at 620 . In the U.S., policymakers generally have chosen to address labor-market discrimination through legal prohibitions rather than tax subsidies or other measures. Therefore, this Comment focuses on changing the legal framework to address weight-based discrimination. 


\section{B. The Benefits of Extending Antidiscrimination Laws to Fat People: Rationales for Extending Legal Protection}

Even assuming that employment discrimination constitutes a market failure, one still faces the question of which types of employment discrimination to address through legal institutions. Since legal regimes entail consumption of scarce resources, a proposal to extend the protection of antidiscrimination laws requires facing the onerous task of justifying protection for the group in question. The following section explores two questions. The first is whether fat people are the type of group that deserves the protection of antidiscrimination laws. The second is whether extending protection to this group somehow diminishes the protection available to others.

\section{Why Fat People as a Group Deserve Legal Protection}

Despite the importance of this imquiry, determining how to distinguish between permissible and impermissible discrimination is a question that "has seldom been addressed, much less answered."97 Three rationales for making this determination might be helpful in deciding whether antidiscrimination laws should be extended to protect fat people. One approach is to highlight self-determination, a second considers equality, and a third focuses on fairness. ${ }^{98}$ This section concludes that a combination of the equality and fairness rationales provides the best answer to why fat people deserve legal protection against employment discrinination.

\section{a. Self-Determination}

A belief in the concept of freedom of self-determination might support a decision to extend the protection of employment antidiscrimination laws to fat people. To the extent that we value allowing people to inake choices about their lives, one might argue, it does not make sense to punish them for the consequences of their choices.

This rationale may fail with regard to weight for two reasons. First, it is not clear that being fat is a choice rather than an immutable characteristic, and as a result, the self-determination framework is an awkward fit. ${ }^{99}$ Second, there is a difference between allowing people the freedom to make choices about how they live their lives and preventing employers from using those choices when making hiring decisions. As Robert Post has pointed out, people may choose to use their physical appearance to

97. Larry Alexander, What Makes Wrongful Discrimination Wrong? Biases, Preferences, Stereotypes, and Proxies, 141 U. PA. L. REV. 149, 152 (1992).

98. See Robert Post, Prejudicial Appearances: The Logic of American Antidiscrimination Law, 88 CALIF. L. REv. 1, 4-6 (2000).

99. A similar problem arises when trying to address sexual orientation discrimination within a self-determination framework. 
communicate a message. It is then difficult, however, to ask employers to ignore that message. ${ }^{100}$ In other words, the employee's interest in selfdetermination exists in tension with the einployer's right "to present a particular image of her business."101 Therefore, while a self-determination approach might provide some support for combating discrimination against fat people, it is ultimately unsatisfactory.

\section{b. Equality}

The most basic definition of equality, treating individuals uniformly, ${ }^{102}$ does not go very far toward providing a principled distinction between groups that deserve legal protection from employment discrimination and those that do not. A rationale that focuses on equality for groups, however, is more helpful. This type of rationale is best viewed as one concerned with dismantling "status hierarchies."

Professor J.M. Balkin argnes that the U.S. Constitution is hostile to status hierarchies. He points to the Reconstruction Amendments, Bills of Attainder, ${ }^{103}$ and Titles of Nobility clauses as evidence of this hostility. ${ }^{104}$ The difficult question is which types of status hierarchies are unjust and should be dismantled and which are permissible either because they are perceived as fair or because they have little effect. Balkin singles out as problematic those hierarchies "where status identity is a central feature of one's social existence, and affects many different spheres of one's life." 105

Immutability is not the crucial feature of this inquiry; rather the central question is whether the trait at issue has been used to "create a system of social meanings or define a social hierarchy that helps dominate and oppress people." ${ }^{106}$ Being fat is certainly a central feature of a person's life and affects spheres of activity ranging from employment to transportation to food and clothing. Body size has seemingly been used as a category to create social meanings that oppress fat people and benefit thin people.

100. Post, supra note 98 , at 5 .

101. Id.

102. Webster's defines "equally" to mean "an equal or uniform manner." WeBster's New Collegiate Dictionary 420 (9th ed. 1983).

103. A bill of attainder is a "law that legislatively determines guilt and inflicts punishment upon an identifiable individual without provision of the protections of a judicial trial." Nixon v. Adm'r of Gen. Serv., 433 U.S. 425,468 (1977).

104. J.M. Balkin, The Constitution of Status, 106 YALE L.J. 2313, 2359 (1997). The Thirteenth Amendment, he notes, abolished slavery and called for "extirpation of its "badges and incidents." 1 d. at 2436 (quoting The Civil Rights Cases, 109 U.S. 3, 20 (1883)). The Fourteenth Amendment abolished "class legislation." Id. at 2437. The Bill of Attainder clause is designed to keep government from "singling out and punishing identifiable groups because of who they are." Id. at 2349-50. Finally, he states that the Titles of Nobility Clauses were designed to abolish an entire social system of superiority and inferiority." Id. at 2350.

105. Id. at 2360 .

106. Id. at 2366 . 
While the idea of combating status hierarchies is a compelling one, the criteria Balkin identifies for making such a determination still seem so vague as to encompass almost any identifiable group. Therefore, Balkin's analytic framework alone does not provide a satisfactory answer about which groups deserve legal protection from employment discrimination.

In the context of the Constitution's Equal Protection Clause, ${ }^{107}$ Owen Fiss proposes what he calls the "group-disadvantaging principle" as an alternative to the "antidiscrimination principle." $108 \mathrm{He}$ critiques the antidiscrimination principle, which is concerned with the fit between means and ends, as a "limited conception of equality" that is too individualistic and does not address the balance of advantage. ${ }^{109}$ By this he means that the antidiscrimination principle is about formal equality. ${ }^{110}$ It does not recognize social classes. ${ }^{11}$ Under the group-disadvantage principle, groups that constitute a perpetual underclass should receive relief. ${ }^{112}$ He bases this idea on the ethical view that caste is undesirable and social groups should not be in subordinate positions for any long period of time. ${ }^{113}$ His rationale is three-fold: he is concerned about (1) "preserving social peace"; (2) "maintaining the community as a community"; and (3) "permitting the fullest development of the individual members of the subordinated group." 114

Fiss outlines two characteristics of groups. First, they have a "distinct existence apart from [their] members." "115 In other words, people in groups identify themselves by reference to group membership. Second, the wellbeing and identity of the group and the meinbers of the group are interdependent. ${ }^{116}$ Fat people arguably fit within this framework. People usually see their body size as part of their identity. Furthermore, the generalizations that exist about fat people as a whole show that they are seen as part of an identifiable group. ${ }^{117}$ Fmally, improving the situation of all fat people will help each individual. Therefore, both group identity and well-being are closely connected to the identity and well-being of the individual members of the group.

The rationales Fiss provides for addressing group disadvantage certainly are compelling. Eliminating discrimmation based on body size will

107. U.S. ConsT. amend. XIV, $\$ 1$.

108. Owen Fiss, Groups and the Equal Protection Clause, 5 PHIL. \& Pub. AfF. 107, 108-09

(1976).

109. Id. at $108,110,117$.

110. Id. at 119-20.

111. Id. at 123.

112. Id. at 151 .

113. Id.

114. Id.

115. Id. at 148.

116. Id.

117. See supra Part 1.B. 
permit personal and economic development of the individual members of the subordinated group. ${ }^{118}$ Furthermore, ending such discrimination will enhance our community and thereby preserve social cohesion. Thus, the equality rationales articulated by both Fiss and Balkin certainly appear to extend legal protection to the fat. Nevertheless, these frameworks are somewhat unsatisfactory because it is hard to determine a logical stopping point; thus, they may not sufficiently limit the number and variety of groups that could qualify for protection.

\section{c. Fairness}

A fairness rationale adds to the equality rationale by providing compelling justifications for legal rules prohibiting weight-based discrimination while still limiting the number of groups that receive legal protection from discrimination. Since there is rarely a correlation between a person's weight and her ability to perform a job, it seems unfair to deny fat people employment opportunities based on this characteristic. ${ }^{119}$

John Rawls has convincingly argued for a conception of social justice derived from a fair procedure. ${ }^{120} \mathrm{He}$ contends that social institutions are just when there are no arbitrary distinctions made among people in the assignment of basic rights and duties. ${ }^{121}$ Furthermore, Rawls is concerned that "accidents of natural endowment" not be used to achieve economic advantage. ${ }^{122}$ His conception of justice goes beyond equal opportunity, since to treat everyone equally, society must give more attention to those with fewer assets and to those born into less favorable situations. ${ }^{123}$ Rawls employs the metaphor of the "veil of ignorance" to illustrate his idea: if one does not know what attributes one would possess in society, one would be inclined to choose a system characterized by fairness for determining the principles of justice. ${ }^{124}$ Justice as fairness provides a further rationale for extending the protection of antidiscrimination laws to fat people. If one were behind a veil of iguorance and did not know what one's weight would be and, further, if weight is immutable to a large degree, one would likely be inclined to choose a system that did not discriminate against fat people.

However, a fairness rationale, while limiting, might still apply to too large a group. There are innumerable characteristics that bear no relationship to one's ability to contribute to society that might be a possible basis

118. Mason, supra note 86 , at 346 ("[a]n individual's well-being is benefited when he or she is challenged by his or her work, and when skills or training can be utilized and developed on the job").

119. Elizabeth M. Adamitis, Appearance Matters: A Proposal to Prohibit Appearance Discrimination in Employment, 75 WASH. L. REV. 195, 212-13 (2000).

120. John Rawls, A TheORY OF Justice 10 (rev. ed. 1999).

121. Id. at 5 .

122. Id. at 14 .

123. Id. at 86 .

124. Id. at 11 . 
for discrimination. Using iminutability as a threshold for protection does not provide a satisfying distinction. Limiting antidiscrimination protection to imunutable traits is both over- and under-inclusive. The following Part examines combining the equality and fairness rationales in the context of immutable and nonimmutable characteristics in order to determine whether a blended rationale would provide a satisfactory principle.

\section{d. Combining Equality and Fairness Concerns}

As described above, the fairness rationale is most effective when applied to immutable characteristics. Nevertheless, immutability is neither necessary nor sufficient as a limiting principle in antidiscrimination law. Therefore, this Comment argues that combining the fairness and equality rationales provides the best solution. It connects the fairness rationale's emphasis on eliminating discrimination on the basis of a characteristic that has little or no relationship to one's ability to contribute in the workplace, with the equality rationale's emphasis on eliminating group hierarchies. Melding these two ideas provides support for extending employment antidiscrimination laws to fat people, because weight has little or no relationship to one's ability to contribute in the workplace and fat people as a group have been subordinated and stigmatized in society.

Protecting people on the basis of immutable traits alone is not satisfactory. An "immutable traits" antidiscrimination law would be overinclusive to the extent that it protects people with characteristics that have not been the basis for social hierarchy. For example, protecting people on the basis of eye color or baldness would not make sense in our current social regime since those traits have not been the sole basis of discrimination against a socially oppressed group. However, if eye-color discrimination were associated with racial or national-origin discrimination, it might then be a characteristic that warranted inclusion in antidiscrimination laws.

If a company decided to hire only people with blue eyes, for example, that policy would certainly have a disparate impact along racial lines. Few people of color have blue eyes but many white people do. An eye-color policy like the one hypothesized here would almost certainly result in an all-white workforce. One way to attack a policy like this would be through disparate impact theory. ${ }^{125}$ However, that legal framework is both difficult

125. Disparate impact theory allows plaintiffs to attack employment policies that have an adverse effect on particular groups of workers, even if the policies were not adopted with discriminatory intent. For example, in the case that established disparate impact theory, Griggs v. Duke Power Co., 401 U.S. 424 (1971), the Supreme Court held to be discriminatory employer requirements that disqualified African-American applicants at a "substantially higher rate" than white applicants. Id. at 425-26. The Court so held despite its finding that the employer did not intend to discrimmate. Id. at 432 . The Court found invalid these types of "built-in headwinds" that disadvantaged people of color and were "unrelated to measuring job capability." Id. 
to use and under fire from the Supreme Court. ${ }^{126}$ Therefore, under the combined equality and fairness approach, if eye-color discrimination were widespread, it should receive separate protection as a category for which plaintiffs could bring disparate treatment claims.

A similar analysis applies when considering baldness. As with eye color, baldness as an employment criterion is not a problem unless it is being used to enforce status hierarchies. For example, if a company had a policy of hiring only bald people (not people who shaved their heads, not people who lost their hair because of chemotherapy, but people who were naturally bald or balding) it would be very likely to have an all-male workforce. As discussed above, since disparate impact theory is difficult to apply, baldness (or absence thereof) would be a protected category if it were used to discriminate against women, who have been historically excluded from full participation in society.

Using immutability as the standard for judging which groups need protection could also be underinclusive. For example, it would not protect people from religious discrimination since people are arguably not born with a religion and religion is certainly not immutable. And at least among those who argue that sexual orientation is voluntary, the immutability standard would not protect people from sexual-orientation discrimination. Even if religion or sexual orientation is mutable, I would still argue that these categories deserve protection to the extent they are associated with subordinated social groups. ${ }^{127}$

Therefore, while "justice as fairness" provides a compelling framework for extending antidiscrimination protection to fat people, it is more effective when combined with both the Balkin status hierarchy approach and Fiss's concern with dismantling caste. While fairness is important, and ideally employers would not make decisions based on characteristics bearing no relation to an employee's ability to do the job, because we have limited resources, antidiscrimination laws should only be extended when the

126. In Wards Cove Packing Co. v. Atonio, 490 U.S. 642 (1989), the Court seriously limited disparate impact theory. Congress reacted to Wards Cove by amending Title VII to add section 703(k) and provide statutory support for disparate impact claims. MICHAEL J. ZIMMER ET AL., CASES AND MATERIALS ON EMPLOYMENT DisCRIMINATION 385 (5th ed. 2000). Nevertheless, since the disparate impact model of antidiscrimination law requires complicated statistical proof, it often is unsatisfactory.

I27. Kentucky law protects smokers from employment discrimination. In the framework this Comment has established, smokers should not be protected by antidiscrimination laws smoking is associated with some other protected group. For example, if one could show that women or people of color were more likely to smoke, the law law would be more justifiable. See Ky. Rev. Stat. AnN. $\S 344.040$ (1) (Banks-Baldwin 2001). Washington, D.C. has an ordinance that protects people from discrimination based on matriculation. See D.C. CODE ANN. § 1-2501 (2001). Again, unless this characteristic is associated with an oppressed group, it does not deserves protection under antidiscrimination laws. 
characteristic in question is associated with a group that has been stigmatized and oppressed in society. ${ }^{128}$

\section{e. Practical Difficulties with Combining Equality and Fairness Concerns}

While this analysis so far has answered some of the questions about how to draw lines while extending the protection of antidiscrimination law to some groups and not others, it has not fully addressed the problem. The Balkin and Fiss approaches assume that we know which kinds of status hierarchy and caste are acceptable and which are not. For example, one might argue that people who have served time in jail comprise a stigmatized group that deserves the protection of antidiscrimination laws, especially since their criminal conviction likely would not have any bearing on their ability to contribute as an employee, at least in many circumstances. The analysis put forth here might encompass this group, especially since statistics show that people of color are imprisoned in disproportionately large numbers. ${ }^{129}$ Nevcrtheless, there certainly will be imdividuals who have been stigmatized in society and who do not deserve the protection of antidiscrimination laws, such as child molestcrs. One way to distinguish why these people do not deserve the protection of antidiscrimination laws stems from Owen Fiss's conception of what constitutes a group. Arguably individuals convicted of a particular type of crime do not constitute a group within the meaning of Fiss's definition, since they do not have a "distinct existence apart from [the group's] members," and the well-being and identity of the group and the members of the group are not interdependent.

Alternatively or additionally, one might exclude a group from legal protection where the behavior that defines the group in question is harmful to society as a whole. However, the idea of excluding groups based on harm to society is less helpful than it initially seeins because it is not clear that we have a universal definition of who causes such harn.

While it is difficult to craft a legal rationale that coherently redresses the subordination of oppressed groups, a combination of fairness and equality coines the closest to making sensible principled distimctions. Therefore, to determine whether people "deserve" the protection of

128. This type of approach informs some of the legal scholarship addressing the question of what groups should receive heightened scrutiny under the Equal Protection Clause. See, e.g., Watkins v. U.S. Army, 847 F.2d 1329 (9th Cir. 1988), vacated en banc, 875 F.2d 699 (9th Cir. 1989). Although later vacated by the Ninth Circuit sitting en banc, the first Watkins decision provides a thorough analysis of why sexual orientation should receive heightened scrutiny. The opinion focuses on the history of discrimination against lesbian and gay people as a group, the fact that sexual orientation is so difficult to change as to be immutable for all practical purposes, the idea that sexual orientation does not bear any relationship to the group's ability to contribute to society, the harm the group suffers because of inaccurate stereotypes or prejudice, and the group's political powerlessness. Id. at 1345-46, 1348.

129. See, e.g., Paul Butler, Affirmative Action and the Criminal Law, 68 U. CoLo. L. REv. 841, 841 n.3 (1997) (stating that "African-Americans are incarcerated at a rate of more than six times that of whites"). 
antidiscrimination laws, this Comment argues for consideration of the following three elements: first, whether the trait in question prevents one from contributing in society; second, whether one is part of an identifiable group; third, whether that group has been subordinated or stigmatized in society.

\section{Why Extending Legal Protection to Fat People Enhances Rather than Diminishes Antidiscrimination Law}

Because this initial analysis potentially sweeps so many groups into antidiscrimination law's protection, another significant question needs to be addressed: whether providing protection to fat people in some way takes away from the protection for other oppressed groups. A reduction in protection for others seems unlikely. In fact, since there is a connection between being fat and other axes of oppression such as sex, race, and class, ${ }^{130}$ providing protection against weight discrimination is likely to enhance the protection available to groups already within the ambit of antidiscrimination laws. ${ }^{131}$ To the extent that weight discrimination has a disparate impact on women and people of color, ${ }^{132}$ ordinances prohibiting weight-based discrimination will increase protection for these groups since they will not have to establish the elements of a disparate impact claim. Instead, they can use disparate treatment analysis with a focus on weight discrimination. ${ }^{133}$

Nevertheless, some people might argue that adding fat as a protected category in some sense takes away from the legitimacy of antidiscrimination laws as they apply to the traditional Title VII categories of race, color, sex, national origin, and religion. ${ }^{134}$ The protection established by Title VII was of crucial importance. However, the five categories listed in that statute do not include all the forms of invidious discrimination that need to be eliminated in society. While the idea of adding additional categories to Title VII is politically risky, adding additional bases of discrimination to state and local antidiscrimination laws may not pose the same dangers.

Assuming that the reader is convinced that fat people deserve to be free of employment discrimination, the next question might be whether existing antidiscrimination laws already provide the necessary protection. The following Part reviews three potential strategies for securing legal protection for fat people through existing federal, state, and local laws.

130. See infra Part 1V.B.

131. Mason, supra note 86 , at 345 (arguing that prohibiting weight-based discrimination would "complement existing antidiscrimination statutes").

132. See infra Part IV.B.

133. A plaintiff proceeds under a disparate treatment claim by arguing she has been "singled out and treated less favorably" than other similarly situated workers. Jauregui v. City of Glendale, 852 F.2d 1128,1134 (9th Cir. 1988).

134. These Title VII categories are outlined at 42 U.S.C. $\$ \$ 2000 e-2(a)(1)(1994)$. 


\section{IV \\ Possible Remedies for Employment Discrimination Against Fat PEOPLE}

There are a number of possible legal remedies for people facing weight-based employment discrimination. As discussed above, someone like Toni Cassista might attempt to invoke federal or state disability antidiscrimination laws to obtain protection. She might consider whether the weight-based discrimination she experienced was tied to her sex or race, and then use Title VII or state race and sex antidiscrimination laws to her benefit. The following Part discusses these legal approaches and concludes that they are of limited use. It then examines changes in California's state disability antidiscrimination law that might make it a more viable tool for victims of weight discrimination in that state. Finally, it discusses the more straightforward approach of adding weight as a protected category to be covered by state and local antidiscrimination laws.

\section{A. Antidiscrimination Laws That Protect People with}

Disabilities: Bringing Claims Under the Disability or Perceived Disability

\section{Framework}

There are compelling arguments for protecting fat people with federal and state disability antidiscrimination laws. While the following Part explores these arguments, this Comment does not advocate expanded use of existing federal disability antidiscrimination laws for five reasons. ${ }^{135}$ First, courts have been generally unsympathetic to claims by fat plaintiffs under the Americans with Disabilities Act ("ADA") and the Rehabilitation Act. ${ }^{136}$ Second, where courts have accepted a disability or perceived disability argument, the plaintiffs generally have been "morbidly obese" rather than "obese" or "overweight." "137 Therefore, using a disability or perceived disability framework would likely protect only the fattest individuals and permit discrimination against people who are heavy but not medically obese. Third, the Supreme Court recently limited the scope of the ADA by

135. For articles discussing federal disability laws as they apply to weight discrimination see, for example, Jeffrey Garcia, Note, Weight-Based Discrimination and the Americans with Disabilities Act: Is There an End in Sight?, 13 HofSTRA LAB. L.J. 209, 233 (1995) (arguing that the Americans with Disabilities Act's definition of disability should be expanded to provide protection for people who are "obese"); Korn, supra note 6, at 27 (concluding that obesity should be considered an actual or perceived disability); Kramer \& Mayerson, supra note 36 , at 72 (stating that obesity discrimination is well suited for protection under the ADA's perceived disability framework); and Christine L. Kuss, Absolving a Deadly Sin: A Medical and Legal Argument for Including Obesity as a Disability Under the Americans with Disabilities Act, 12 J. CONTEMP. HeAlTH L. \& PoL'Y 563, 568 (1996) (arguing that "morbid obesity should, and moderate and mild obesity can, be entitled to disability status under the ADA").

136. See infra Part IV.A.1.

137. See infra Part IV.A.1.c. 
finding states immune from suit under the Eleventh Amendment. ${ }^{138}$ Fourth, using disability antidiscrimination laws is problematic from an ideological perspective, since most fat people would argue that they are not disabled and are in fact perfectly capable of doing the same work as thin people. ${ }^{139}$ Finally, using the disability framework requires adopting the medical language associated with fat such as overweight, obesity and morbid obesity. As discussed above, these terms are charged with negative meaning. Since they are the words used by the courts, however, this part of the Comment uses terms explicitly rejected in earlier sections.

Despite all these objections to the disability framework, the following Part will provide a brief overview of the possible legal arguments that might lead to protection for fat people under existing federal and state disability antidiscrimination laws. As one author has noted, "in the absence of protection specifically geared toward weight discrimination, the obese must continue to try to fit their claims into the uncomfortable structure of disability statutes." 140 Thus, as a practical matter, it is important for advocates to be aware of disability antidiscrimination laws and how they have been applied to fat plaintiffs.

Another important reason to review disability antidiscrimination laws is the fact that some states provide disability discrimination protection that differs from federal law in siguificant ways. For example, California's amended Fair Employment and Housing Act ("FEHA") breaks with the $\mathrm{ADA}$ and provides a less onerous test for establishing perceived disability. ${ }^{141}$ Therefore, this Comment ultimately concludes that victims of weight discrimination should be aware of the greater legal protection and less politically objectionable language provided by state laws as well as the more limited federal-law avenues.

\section{Federal Law: The Americans with Disabilities Act and the Rehabilitation Act of 1973.}

Under the $\mathrm{ADA}^{142}$ and the Rehabilitation Act of $1973,{ }^{143}$ a person qualifies as disabled if she has a present "physical or mental impairment"

138. See Bd. of Trs. of Univ. of Alabama v. Garrett, 531 U.S. 356 (2001).

139. Goldberg, supra note 17, at A3 (quoting Sondra Solovay).

140. Patricia Hartnett, Note, Nature or Nurture, Lifestyle or Fate: Employment Discrimination Against Obese Workers, 24 RuTGERS L.J. 807, 826 (1993).

141. See infra Part IV.A.2.c.

142. 42 U.S.C. $\$ \$ 12101-12213$ (1995).

143. 29 U.S.C. $\$ \S 701-794$ (2001). The Rehabilitation Act was amended in 1990 so that its current provisions mirror those of the ADA. ZIMMER, supra note 126, at 741. Therefore, this Part will not elaborate on the pre-amendment differences between the two laws. It is important to note, however, that the Rehabilitation Act's coverage focuses on entities that receive federal funding; therefore, its provisions might still bind state governments despite the Supreme Court's decision that states are immune from suit under the $\mathrm{ADA}$ due to the Eleventh Amendment. Bd. of Trs. of Univ. of Alabama v. Garrett, 531 U.S. 356, 360 (2001). 
that "substantially limits" one or more "major life activities," or has a record of such an impairment, or is regarded as such. ${ }^{144}$ The ADA, the Equal Employment Opportunity Commission ("EEOC") regulations and guidance, and case law give meaning to each of these terms. Additionally, an individual seeking ADA protection would also have to show that she was qualified for the job in question, meaning that she could perform the essential functions of the position with or without reasonable accommodation. ${ }^{145}$

\section{a. Establishing a Present Impairment}

EEOC regulations define impairment with reference to various physical disorders or conditions. ${ }^{146}$ The EEOC's Interpretive Guidance on Title I of the ADA specifically states that "except in rare circumstances" obesity is not a "disablimg impairment."147 The presumption is that a person's weight is not an impairment. Thus, to gain protection from weight-based discrimination under the present impairment prong of the ADA, a plaimtiff

144. The ADA's definition of disability is found at 42 U.S.C. $\$ 12102(2)$ (1995). The Rehabilitation Act's definition is at 29 U.S.C. $\$ 706(8)(2001)$.

145. See 42 U.S.C. $\S 12111$ (8) (1995). Because courts have generally found that fat workers were not able to establish a disability under any of these definitional prongs of the ADA and the Rehabilitation Act, they generally have not reached the issue of whether the worker was qualified. The ADA defines "qualified" as being able to perform the essential functions of the job in question with or without a reasonable accommodation. 42 U.S.C. $\$ 12111$ (8) (1995). While a detailed examination of these issues is outside the scope of this Comment, the following cases provide some examples of the way courts treat the qualification issue when faced with morbidly obese plaintiffs.

The First Circuit admonished an employer that its assessment of an applicant's qualifications must be objectively reasonable and not based on "stereotypes and broad generalizations." Cook v. Rhode Island, Dept. of Mental Health, Retardation \& Hosps. 10 F.3d 17, 22 (1st Cir. 1993). It then held that a jury could reasonably have found that the plaintiff was qualified for an institutional attendant position, $i d$. at 27-28, since a prehire physical showed no limitations that would have prevented her from doing the job, and she had performed satisfactorily in her previous employment with the defendant. Id. at 2021.

Similarly, in EEOC v. Texas Bus Lines, 923 F. Supp. 965 (S.D. Tex. 1996), the court found that a morbidly obese bus driver candidate was qualified for the position based on the fact that the company initially decided to hire her and found her "very impressive." Id. at 971 . The only reason she was not ultimately hired was her failure to pass the required medical examination because the doctor perceived her weight as a safety risk. Id. The court characterized this medical conclusion and the employer's subsequent decision not to hire the candidate as one that was based on the "perceived and mistaken belief" that the candidate was disabled because of her weight. Id. Because it was inproper for defendant to rely on an erroneous niedical opinion, $i d$. at 973 , the court concluded that the bus driver candidate was "qualified" within the meaning of the ADA. Id. at 974.

146. The regulations define impairment as "[a]ny physiological disorder or condition, cosmetic disfigurement, or anatomical loss affecting one or more of the following body systems: neurological, musculoskeletal, special sense organs, respiratory (imcluding speech organs), cardiovascular, reproductive, digestive, genito-urinary, hemic and lymphatic, skin, and endocrine." 29 C.F.R. $\S 1630.2(\mathrm{~h})(1)(2001)$.

147. 29 C.F.R. pt. 1630, app. $\S 1630.2(j)(2001)$. 
must show that she is fat because of a covered impairment (such as a thyroid dysfunction). ${ }^{148}$

In Cook v. Rhode Island Department of Mental Health, Retardation, $\&$ Hospitals, ${ }^{149}$ the First Circuit found that a morbidly obese plaintiff qualified as disabled under the "present impairment" prong after she presented evidence that her weight was a "dysfunction of both the metabolic system and the neurological appetite-suppressing signal system," and could cause adverse effects to the "musculoskeletal, respiratory, and cardiovascular systems."150

Despite the helpful decision in Cook, it is difficult for fat plaintiffs to establish that their weight constitutes a present impairment under the ADA. For example, in Coleman v. Georgia Power Co. ${ }^{151}$ the court read Cook to allow a finding that obesity is a present impairment only when it both affects "one of the bodily systems outlined in the gnideline definition for physical impairment and where such obesity is related to a physiological disorder." 152 The Coleman court went on to find that the plaintiff had not shown that his morbid obesity constituted a physiological disorder and therefore did not qualify as disabled under the "present impairment" prong. ${ }^{153}$ The court then opined that such a result was necessary to avoid "dilution of the $\mathrm{ADA}$ " resulting from including appearance or size as protected categories. ${ }^{154}$ Thus, while the Cook court was willing to read the ADA to allow a morbidly obese plaintiff to establish a present impairment, its analysis focused on the present and future medical effects of the plaimtiff's weight.

Other courts have interpreted the $\mathrm{ADA}$ more narrowly to require medical evidence of a physiological disorder. For example, a plaintiff who presented no expert testimony about his obesity and its effect on his body systems was held not presently impaired. ${ }^{155}$ Thus, in some cases a morbidly obese plaintiff might prevail under the "present impairment" prong, but the present impairment part of the ADA's definition of disability is generally unavailing for victims of weight discrimination.

148. She must also demonstrate that she is substantially limited in a major life activity and that she is qualified for the job in question.

149. 10 F.3d 17 (1st Cir. 1993).

150. Id. at 23 .

151. 81 F. Supp. 2d 1365 (N.D. Ga. 2000).

152. Id. at 1369 .

153. Id. at 1370 .

154. Id. See also EEOC v. Texas Bus Lines, 923 F. Supp. 965, $975-76$ (S.D. Tex. 1996) (stating in dicta that "courts as well as the ADA have consistently rejected obesity as a disability protected by the $\mathrm{ADA}$ " and that "neither the case law nor the applicable regulations include morbid obesity as a disability under the ADA").

155. Morrison v. Pinkerton, Inc., 7 S.W.3d 851, 855-57 (Tex. App. 1999). See also Nedder v. Rivier College, 944 F. Supp. 111 (D.N.H. 1996) (finding no present impairment). 


\section{b. Establishing a Record of an Impairment}

An individual who no longer has a present impairment might gain ADA protection if she could show she had a sufficient record of such an impairment. ${ }^{156}$ This part of the definition was included primarily to protect former cancer patients from discrimination. ${ }^{157}$ In Morrison v. Pinkerton, Inc., ${ }^{158}$ a plaintiff attempted to show that he had been overweight most of his life in order to state a claim under the "record of" prong of the Texas disability antidiscrimination law (which uses the same basic standards and definitions as the ADA and the Rehabilitation Act). ${ }^{159}$ Since the plaintiff was not able to produce any records of his impairment, the court rejected his claim under the "record of" prong. ${ }^{160}$

A plaintiff who was able to produce records of his obesity fared no better in Coleman v. Georgia Power Co ${ }^{161}$ There, the court found that such records were not enough. Instead the court stated that to prevail, the plaintiff would have had to produce records that showed he had been classified "as having an impairment that substantially limited a major life activity."162 Thus, both the "present impairment" and the "record of an impairment" prongs of the definition of disability have provided little relief for victions of weight discrimination.

\section{c. Establishing a Perceived Disability}

Intuitively, it would seem that the "regarded as" prong of the ADA definition of disability would provide protection to people who are stigmatized in society because of physical characteristics. Since fat people have been stigmatized in this manner, they arguably should receive the same protection as people who are "regarded as" disabled. Nevertheless, courts have interpreted this prong narrowly to deny such protection. The promise of this prong of the definition of disability was hinted at in the EEOC regulations and interpretive guidance, which explained that there were three ways a person could be "regarded as" having a disability within the meaning of the statute. ${ }^{163}$

First, the person might have soine impairment that did not substantially limit a major life activity but caused her einployer to treat her as if

156. Having a record of an impairment is one way of showing disability under the ADA or the Rehabilitation Act. 42 U.S.C. $\$ 12102$ (2) (1995); 29 U.S.C. $\$ 706(7)(B)$ (2001).

157. EEOC Interpretive Guidance on Title 1 of the Americans with Disabilities Act, 29 C.F.R. pt. 1630 , app. $\S 1630.2(\mathrm{k})(2001)$ [hereinafter Interpretive Guidance].

158. 7 S.W.3d 851 (Tex. App. 1999).

159. Id. at $854 \mathrm{n} .4,857$.

160. Id. at 857 .

161. 81 F. Supp. 2 d 1365 (N.D. Ga. 2000).

162. Id.

163. 29 CFR $\$ 1630.2(I)$ (2001); Interpretive Guidance, supra note $157, \S 1630.2(l)$. 
she had such a limitation. ${ }^{164}$ For example, an employer assigning an employee with high blood pressure to less strenuous work would be treating this worker as if she had a substantially limiting impairment even though she did not. ${ }^{165}$ Second, a person might have an impairment that substantially limited a major life activity but only because of attitudes of others toward the impairment. ${ }^{166}$ The example from the guidance concerns a person with a facial scar or disfigurement. ${ }^{167}$ This part of the guidance approach attempts to account for the real world effects of being stigmatized for a physical condition that would not otherwise be substantially limiting. Obesity might well fall within this type of disability discrimination. Finally, a person might not have any impairment but her employer might treat her as if she had a substantially limiting impairment. ${ }^{168}$ For example, the employer might act on a false rumor that an employee had HIV. ${ }^{169}$ Thus, it would seem that the EEOC contemplated that stigmatizing conditions such as obesity should receive coverage under the "regarded as" prong. Courts, however, have been rather unsympathetic to this interpretation. The Cook decision, noted above, provides a notable exception to this trend.

\section{i. Cases Where Courts Sustained Perceived Disability Claims Brought by Morbidly Obese Plaintiffs}

Cook v. Rhode Island Department of Mental Health, Retardation, \& Hospitals $^{170}$ provides a rare appellate court example of the successful use of the "regarded as" prong of federal disability antidiscrimination law, in this case the Rehabilitation Act, to protect someone who was "morbidly obese." In Cook, the First Circuit allowed a perceived disability claim brought by a fat woman who was denied employment because of her weight. ${ }^{171}$ Bonnie Cook, who was morbidly obese, applied for a position as an institutional attendant for the mentally disabled. She was denied employment although a prehire physical revealed no limitations that would prevent her from performing the job. ${ }^{172}$ The defendant claimed that it did not hire her because her weight would prevent her from being able to

164. 29 CFR $\S 1630.2(l)(2001)$.

165. Interpretive Guidance, supra note $157, \S 1630.2(l)$.

166. 29 CFR $\S 1630.2(l)(2001)$.

167. Interpretive Guidance, supra note $157, \S 1630.2(l)$.

168. 29 CFR § $1630.2(l)(2001)$.

169. Interpretive Guidance, supra note $157, \S 1630.2(l)$.

170. 10 F.3d 17 (1st Cir. 1993).

171. Id. at 28 .

172. Id. at 20-21. She was 5'2" tall and weighed over 320 pounds. Id. at 20 . While she had been fat when she worked for the defendant in the past, she had not been "morbidly obese." Id. at 20 n.l. 
evacuate patients in an emergency and would put her at risk for developing future illnesses. ${ }^{173}$

Ms. Cook sued under the Rehabilitation Act and prevailed in a jury trial. ${ }^{174}$ The court found that the plaintiff could prevail on the "present impairment" prong. ${ }^{175}$ Alternatively, it found that she could establish that the defendant regarded her as having such an impairment. ${ }^{176}$ With respect to definition of the "regarded as" prong, the court found that the defendant treated the plaintiff as if her obesity "actually affected her musculoskeletal and cardiovascular systems." 177 The court rejected the defendant's argument that obesity was mutable and therefore not a covered impairment. ${ }^{178}$ Essentially, the court found that even if obesity could be mitigated through fasting, the underlying condition remained. ${ }^{179}$ Furthermore, the court found that as long as the employer regarded the impairment as immutable, whether the condition was in fact immutable was not important in a perceived disability claim; ${ }^{180}$ mutability itself was relevant only to whether the impairment was substantially limiting. ${ }^{181}$ The court also rejected the defendant's argument that the plaintiff's obesity was caused by voluntary conduct and therefore was not a covered disability. It found instead that the Rehabilitation Act covered a number of conditions that were "caused or exacerbated by voluntary conduct."182

Once the court found that obesity could be an impairment, it considered whether the employer regarded the impairment as substantially limiting the plaintiff in one or more major life activities. ${ }^{183}$ The court found that the defendant viewed the plaintiff as being substantially limited in the major life activity of working despite the fact that she "applied for and was rejected from only one job." 184 The court reasoned that a plaintiff need not "subject herself to a lengthy series of rejections at the hands of an insensitive employer to establish that the employer view[ed] her limitations as substantial," so long as the employer treated the plaintiff as having a condition that would disqualify her from a range of jobs. ${ }^{185}$

173. Id. at 21. For a case with similar facts, see EEOC v. Texas Bus Lines, 923 F. Supp. 965 (S.D.

Tex. 1996), discussed supra at note 145 .

174. Cook, 10 F.3d at 21.

175. Id. at 23.

176. Id.

177. Id.

178. Id. at 23-34.

179. Id. at 24 .

180. Id.

181. Id.

182. Id. (stating that the Rehabilitation Act applies to a number of disabilities that may be caused or made worse by voluntary conduct including "alcoholism, AIDS, diabetes, cancer resulting from cigarette smoking, heart disease resulting from excesses of various types, and the like").

183. Id. at 25 .

184. Id.

185. Id. at 26 . 
Although the Cook court's reasoning might protect only those people who qualify as morbidly obese, it has still been a useful tool for several such plaintiffs fighting weight discrimination. For example, in Nedder $v$. Rivier College, ${ }^{186}$ a morbidly obese plaintiff claimed that her employer regarded her as substantially limited in the major life activity of working. ${ }^{187}$ The district court denied summary judgment to the defendant, since two people who decided that the plaintiff's contract should not be renewed specifically stated that students perceived overweight teachers to be less intelligent and less disciplined. ${ }^{188}$ The plaintiff ultimately prevailed at trial, winning reinstatement and $\$ 137,500$ in damages. ${ }^{189}$

In Florida, the Cook decision persuaded the state court in Greene $v$. Seminole Electric Cooperative, Inc. ${ }^{190}$ to find that a plaintiff's morbid obesity could qualify as a perceived disability under that state's disability antidiscrimination statute (which is similar to the $\mathrm{ADA}$ ). ${ }^{191}$ The court reasoned that morbid obesity could be perceived as substantially limiting the major life activity of working. ${ }^{192}$ Since the defendant in Greene conditioned the plaintiff's probationary period as a groundskeeper on him losing weight and refused him a mechanic position because of his weight, the court found that the plaintiff made a sufficient showing that the defendant perceived him as disabled to survive dismissal of his complaint. ${ }^{193}$

Likewise, in EEOC v. Texas Bus Lines, ${ }^{194}$ a Texas district court found that a morbidly obese woman who was denied employment as a bus driver could state a clain under the "regarded as" prong of the ADA. ${ }^{195}$ In this case, the physician who examined the candidate in a pre-employment medical screening found that she would not be able to move quickly enough if there was an accident. ${ }^{196}$ The doctor later admitted that his conclusion was based on observing the potential employee getting up from her seat in the waiting room and "waddling" into the examining room. ${ }^{197} \mathrm{He}$ did not perform any additional agility or mobility tests during the five-or six-minute exam he administered. ${ }^{198}$

A representative of Texas Bus Lines had observed the candidate during the initial interview, and his observations of the candidate did not

186. 944 F. Supp. 111 (D.N.H. 1996).

187. Id. at 119.

188. Id. at 119-120.

189. Nedder v. Rivier College, 972 F. Supp. 81, 82-83 (D.N.H. 1997).

190. 701 So. 2d 646 (Fla. Dist. Ct. App. 1997).

191. Id. at 647.

192. Id.

193. Id.

194. 923 F. Supp. 965 (S.D. Tex. 1996).

195. Id. at 979.

196. Id. at 967 .

197. Id. at 968 .

198. Id. at 978 . 
confirm the doctor's view. ${ }^{199}$ In fact, he stated that the applicant was no heavier than many of the company's other drivers. ${ }^{200}$ Furthermore, since the company could have sent the candidate to another doctor for an exain if it disagreed with this doctor's conclusion, the court found that the defendant failed to hire the candidate because it perceived her to be disabled based on "myth, fear or stereotype."201 The court found it unreasonable for the defendant to claim that it believed it could not hire the candidate because one doctor said she was not agile enough. ${ }^{202}$

These cases demonstrate that some inorbidly obese plaintiffs have been successful in pursuing their perceived disability claims under the ADA, the Rehabilitation Act, and state laws adopting the ADA and Rehabilitation Act standards. The courts in these cases have recognized that the stigma associated with being fat falls within the type of harm that the "perceived disability" definition was designed to prevent.

\section{ii. Cases Where Courts Rejected Perceived Disability Claims Brought by Morbidly Obese Plaintiffs}

Unfortunately, courts in other jurisdictions have read the statutes more narrowly and deuned protection in cases with similar facts. For example, in Morrison v. Pinkerton, Inc. ${ }^{203}$ a Texas court found that a morbidly obese plaintiff did not state a claim under the "regarded as" prong of Texas' state antidiscrimination law, which mirrors the ADA. Although the defendant inade a number of comments about the plaintiff's weight, the court found that the plaintiff did not demonstrate that the defendant regarded him as substantially limited in a najor life activity. ${ }^{204}$

Likewise, in Hazeldine v. Beverage Media, Ltd. ${ }^{205}$ the court held that a plaintiff who was morbidly obese was not regarded as disabled by her employer ${ }^{206}$ As a result, her ADA claim failed, although it was undisputed that her weight did not interfere with her ability to work. ${ }^{207}$ The plaintiff was terminated when the company moved to a smaller office; she contended that her boss told her there was no room for her in the new location because she was a "big girl."208 Nevertheless, the court rejected the plaintiff's argument that her employer perceived her as unable to work because of her size. ${ }^{209}$

199. Id. at 973 .

200. Id.

201. Id. at 979.

202. Id.

203. 7 S.W.3d 851 (Tex. App. 1999); see also supra notes $158-160$ and accompanying text.

204. Id. at 858 .

205. 954 F. Supp. 697 (S.D.N.Y. 1997).

206. Id. at 705 .

207. Id. at 699 .

208. Id. at 701 .

209. Id. at 705 . 
Thus, while the Cook decision has inspired some courts to hold that morbidly obese plaintiffs could prevail on a perceived disability claim, other courts have been less sympathetic. In these latter cases, the courts have taken a more formalistic view of the definition of perceived disability.

\section{iii. Cases Where Courts Rejected Perceived Disability Claims Brought by Obese Plaintiffs}

Plaintiffs who are fat but not morbidly obese also have been unsuccessful when bringing "regarded as" claims. In Walton v. Mental Health Ass'n of Southeastern Pennsylvania, ${ }^{210}$ the Third Circuit refused to allow an obese plaintiff to proceed on a "regarded as" disability claim. ${ }^{211}$ The court stated that it had not recognized obesity as a basis for a cause of action for perceived disability. ${ }^{212}$ It declined to recognize such a claim in Walton's case because she did not allege that her employer regarded her as substantially limited in a major life activity. ${ }^{213}$

Similarly, in Ridge v. Cape Elizabeth School Department, ${ }^{214}$ the court found that the plaintiff failed to establish her perceived disability claim. The plaintiff argued that she was not terminated because of her deteriorating relationship with her supervisor, as the defendant claimed, but rather because of her perceived disability (obesity). ${ }^{215}$ The court rejected the plaintiff's claim that the defendant perceived her to be substantially limited in the major life activities of walking and working. ${ }^{216}$

In Smaw v. Virginia Department of State Police, ${ }^{217}$ the court rejected an obese plaintiff's claim of perceived disability discrimination under the ADA and the Rehabilitation Act. ${ }^{218}$ Smaw was hired as a state trooper "with the understanding that she would reach the appropriate weight during her employment."219 When she failed to lose weight, she was terminated

210. 168 F.3d 661 (3d Cir. 1999).

211. Id.

212. Id. at 665 .

213. Id. According to the court, Walton's main claim of weight-related discrimination was that her employer refused to distribute a work-related video in which she appeared. Id. at 665-66. Since this video related only to a minor aspect of her job, the court reasoned, the plaintiff could not allege that her employer viewed her as substantially limited in the major life activity of working. There was no evidence that the defendant viewed her as substantially limited in any other major life activity. Id. at 666.

214. 77 F. Supp. 2d 149 (D. Me. 1999).

215. Id. at 162. Plaintiff was not "morbidly obese." Id. at 164 n.7.

216. Id. at 163-64. Although her supervisor did inquire as to whether she could handle all the walking required by the expanded library, this inquiry was an isolated one and had occurred over a year before the plaintiff was terminated. Id. at 163 . As to working, the court found the plaintiff did not allege that the defendant perceived her as being unable to work in a broad range of jobs because of her weight. Therefore, the plaintiff's perceived disability claim failed. Id. at 164 .

217. 862 F. Supp. 1469 (E.D. Va. 1994).

218. Id. at 1475 .

219. Id. at 1471 . 
from her position as a trooper but allowed to remain on as a dispatcher. ${ }^{220}$ The court held that Smaw did not show that her einployer regarded her as "incapable of performing duties in her chosen occupation" of law enforcement. ${ }^{22}$ While Smaw argued that her profession encompassed "active law enforcement jobs," the court found instead that the "field of law enforcement as a whole" was the proper reference point. ${ }^{222}$ Since Smaw continued to be employed as a dispatcher, the court concluded that she was not substantially limited and that her employer did not perceive her as such. $^{223}$

Based on these cases, one could conclude that an obese plaintiff who is not morbidly obese is extremely unlikely to succeed using a perceived disability theory. ${ }^{224}$ Therefore, even if the disability framework is able to provide a legal remedy for some fat workers, it is unlikely to protect those who are less fat but who are still experiencing weight-based employment discrimination. ${ }^{225}$

\section{iv. Cases Where Courts Upheld Weight Requirements Despite Disability Discrimination Arguments}

Challenges to workplace weight requirements based on the ADA and the Rehabilitation Act are unlikely to succeed where the plaintiff is inerely "overweight." Claims brought by plaintiffs who have experienced weightbased discrimination but who are not necessarily obese or morbidly obese undergo stringent analysis in the courts. For example, in Francis v. City of Meriden, ${ }^{226}$ the Second Circuit held that a plaintiff who was a firefighter failed to state a perceived disability claim under the ADA or the Rehabilitation Act when his employer disciplined him for failing to comply with weight requirements. ${ }^{227}$

220. Id.

221. Id. at 1475.

222. Id.

223. Id.

224. See supra note 6 for a discussion of the difference between obesity and morbid obesity.

225. One author has argued that courts should draw a bright-line distinction between plaintiffs who are unorbidly obese and those who are just "extremely fat." Andrea M. Brucoli, Comment, Cook v. Rhode Island Department of Mental Health, Retardation, and Hospitals: Morbid Obesity as a Protected Disability or an Unprotected Voluntary Condition, 28 GA. L. REv. 771, 798 (1994).

226. 129 F.3d 281 (2d Cir. 1997).

227. Id. at 282. The court found that the plaintiff had alleged only that he was disciplined for failing to meet the general weight standards of the fire department, not that his employer viewed him as having a "physiological weight-related disorder" as required by the statute. Id. at 285 . The court determined that the defendant did not regard the plaintiff as having an inpairment that substantially limited him in a major life activity within the meaning of the ADA. Id. at 286 . The court went on to find that weight was generally not a covered impairment. It further opined that to recognize it as such would open the door to claims based on various physical conditions such as "height, strength, dexterity, and left-handedness," which were "not meant to be covered by the acts." Id. Although the court may have correctly interpreted the current law, one can inake a principled argument that weight should be protected because of the social stigma attached to being fat without opening the door to claims based on 
Similarly, in Andrews v. Ohio, ${ }^{228}$ state highway patrol officers who were subject to weight limits brought suit under the ADA and the Rehabilitation Act under a perceived disability theory. ${ }^{229}$ The court held that being overweight (without being obese) was merely a physical characteristic rather than a physiological disorder. ${ }^{230}$ Since the plaintiffs had not alleged that the defendant perceived them to have any impairment, their perceived disability claim failed. ${ }^{231}$

In Furst v. New York Unified Court System, ${ }^{232}$ the plaintiff challenged the weight requirements for court officers under the "regarded as" prong of the ADA. ${ }^{233}$ Furst alleged that the defendant held a misperception that he could not perform the job of a court officer. ${ }^{234}$ The court found that this allegation did not amount to a perception that Furst was substantially limited in the major life activity of working. ${ }^{235}$ The defendant only viewed him as incapable of performing one particular job, not a broad range or class of jobs as required by the statute..$^{236}$

As discussed above, ${ }^{237}$ one of the limits of the perceived disability approach is that it is difficult to obtain protection for workers who are fat but not obese. The cases demonstrate that in attacking discriminatory weight requirements, the "regarded as" prong is essentially of no use to these plaintiffs.

However, a plaintiff like Toni Cassista could consider brimging suit under federal laws designed to protect people from disability and perceived disability discrimination. Since Cassista would qualify as "morbidly obese," she might have had some success in bringing a perceived disability claim under the ADA or the Rehabilitation Act if the court followed the more liberal Cook approach. The court, however, might have adopted a narrower interpretation of the statutes and denied her federal claim. In fact,

every type of physical characteristic. See supra Part III. Left-handedness was a historically stigmatized condition. See SolovaY, supra note 13, at 150. If it were still treated as such, the protection of antidiscrimination laws would be appropriate for this group.

228. 104 F.3d 803 (6th Cir. 1997).

229. Id. at 808 .

230. Id. at 810 .

231. Id.

232. No. 97-CV-1502 (ARR), 1999 WL I021817, at *1 (E.D.N.Y. Oct. 18, 1999).

233. Id. at $* 1-* 2$. The plaintiff also alleged that his weight was a prescnt impairment. Id. at *4. The court found that obesity was a present impairment only where a plaintiff was morbidly obese or where his weight condition "is the symptom of a physiological disorder." Id. Since the plaintiff neither suffered from morbid obesity, nor was ever "clinically diagnosed as obesc," his present impairment claim failed. Id.

234. Id. at *5.

235. Id.

236. Id. See also Tudyman v. United Airlines, 608 F. Supp. 739, 740-41, 746 (C.D. Cal. 1984) (holding that a male body builder whose weight exceeded the defendant's weight limits for flight attendants was not disabled under the Rehabilitation Act's definition).

237. See supra Part IV.A.1.c.iii. 
Cassista pursued a state antidiscrimination claim under FEHA and the state court rejected it. ${ }^{238}$

At the time Cassista brought her claim, FEHA was interpreted to mirror the ADA in most significant respects. The legislature recently amended California's FEHA to make the law's protections more effective for people with disabilities and perceived disabilities. ${ }^{239}$ These changes, which were enacted in part to overturn the result in the Cassista case, ${ }^{240}$ suggest that state laws can provide important legal relief for victims of weight-based employment discrimination. The following Part will discuss a number of state disability antidiscrimination laws that provide greater protection against weight-based employment discrimination than the federal laws.

\section{State Disability Antidiscrimination Laws}

A number of states, including New York, New Jersey, and California, have enacted disability antidiscrimination laws that provide more effective relief for victims of weight-based employment discrimination than the ADA or the Rehabilitation Act. Nevertheless, a plaintiff might have political objections to using these laws to the extent that they still require her to argne that being fat is an unhealthy medical condition.

\section{a. New York}

Under New York state law, a person can show she is disabled if her impairment is "demonstrable by medically accepted techniques."241 She does not have to show that her impairment substantially limits her major life activities.

In State Division of Human Rights v. Xerox Corp. ${ }^{242}$ a New York appellate court found in favor of an obese plaintiff on a state disability discrimination claim. ${ }^{243}$ After a pre-employment physical, the company found the plaintiff to be a medically unacceptable candidate because of her weight. ${ }^{244}$ The applicant then filed a complaint of disability discrimination with the state Human Rights Division. ${ }^{245}$ Since her weight was "a physical

238. Cassista v. Community Foods, Inc., 856 P.2d 1143, 1154 (Cal. 1993).

239. See infra Part IV.A.2.c.

240. See infra Part IV.A.2.c.

241. N.Y. ExEc. LAW $\$ 292(21)$ (2001). The statute's full definition of disability is "a physical, mental or medical impairment resulting from anatomical, physiological, genetic or neurological conditions which prevents the exercise of a normal bodily function or is demonstrable by medically accepted clinical or laboratory diagnostic techniques." Id.

242. 480 N.E.2d 695 (N.Y. 1985).

243. Id. at 698 .

244. Id. at 696.

245. Id. At that time, state Executive Law Section 296[20] defined disability as: a physical, mental or medical impairment resulting from anatomical, physiological or neurological conditions with [sic] prevents the exercise of a normal bodily function or is demonstrable by medically acceptable clinical or laboratory diagnostic techniques, provided, however, that in all provisions of this article dealing with employment, the term shall be 
or medical impairment demonstrable by medically accepted clinical diagnostic techniques," the Human Rights Commissioner sustained her complaint. ${ }^{246}$ The Human Rights Board reversed, holdmg that "being overweight without proof of any impairment" was not a covered disability. ${ }^{247}$ It also relied on the fact that the plaintiff's obesity was "voluntary," rather than induced by a glandular or organic deficiency, to reach that conclusion. ${ }^{248}$

The Appellate Division in turn reversed the Board's ruling. ${ }^{249}$ The Division found that there was substantial evidence in support of the Commissioner's initial determination and that the Commissioner's interpretation of the statute was reasonable and showed common sense. ${ }^{250}$ New York's highest court affirmed, finding that the state statute's definition of disability was much broader than that of typical disability statutes. ${ }^{251}$ The court rejected the defendant's argument that the statute should only apply to immutable conditions, finding such an interpretation contrary to legislative intent. 252

Similarly, in Hazeldine v. Beverage Media, Ltd., ${ }^{253}$ a federal district court in New York considered whether a plaintiff's claim of disability discrimination under state law could succeed where her ADA claim failed. ${ }^{254}$ Because the plaintiff was considered morbidly obese, the court relied on Xerox to conclude that she was disabled. ${ }^{255}$ As a result, it denied the defendant's summary judgment motion. 256

\section{b. New Jersey}

New York is not alone. New Jersey law also provides more disability discrimination protection than federal statutes. Fat plaintiffs have succeeded under these laws where an $\mathrm{ADA}$ claim might have failed. The New Jersey Law Against Discrimination provides protection against discrimination based on disability. Individuals suffering "from any mental,

\footnotetext{
limited to physical, mental or medical conditions which are unrelated to the ability to engage in the activities involved in the job or occupation which a person claiming protection of this article shall be seeking. Id.

246. Id. at 696-97.

247. Id. at 697.

248. Id.

249. Id.

250. Id.

251. Id. at 698. But see Underwood v. Trans World Airlines, Inc., 710 F. Supp. 78,84 (S.D.N.Y. 1989) (finding that a flight attendant who was terminated because she exceeded the weight guidelines but was not "obese" did not qualify as having a disability under the New York Human Rights Law).

252. Id. at 698-99.

253. 954 F. Supp. 697 (S.D.N.Y. 1997).

254. Id. at 706 .

255. Id. at 707.

256. Id. at 709.
} 
psychological or developmental disability resulting from anatomical, psychological, physiological or neurological conditions ... demonstrable medically or psychologically, by accepted clinical or laboratory diagnostic techniques"257 fall within its ambit.

In Gimello v. Agency Rent-A-Car Systems, Inc., ${ }^{258}$ a New Jersey court considered a state law discrimination claim brought by an obese plaintiff who was by all accounts an excellent employee. ${ }^{259}$ Gimello's regional manager made numerous inappropriate comments about Gimello's weight, including statements that he was not promotable because of his size $\mathrm{e}^{260}$ and that he was a "fat slob."261 The court concluded that it did not matter whether the plaintiff was fired because of an actual or perceived disability. ${ }^{262}$ It found that the state law definition of disability was "very broad" and that the plaintiff's obesity qualified for disability under that definition since it was physiological and could be demonstrated by "accepted diagnostic techniques."263 Because the plaintiff's employer fired him for a covered condition that did not prevent him from performing his job, he had an actionable employment discrimination claim. ${ }^{264}$

Although states such as New York and New Jersey provide greater protection for victims of weight-based discrimination than federal law, cases where plaintiffs have been successful have focused on obesity as a medical condition. However, a plaintiff might have objections to using these laws to the extent that they still require her to argne that being fat is an unhealthy medical condition. The recent amendment to California's FEHA, discussed in the next Part, addresses some of these concerns.

\section{c. California}

California's FEHA was recently amended in ways that should profoundly expand its protections. ${ }^{265}$ Prior to this amendment, FEHA was

257. New Jersey Stat. ANn. 10:5-5q (West 1993).

258. 594 A.2d 264 (N.J. Super. Ct. App. Div. 1991).

259. The court's opinion details the number of salary increases, bonuses, favorable reviews, and promotions the plaintiff received before this regional manager became his supervisor. Id. at 266-67.

260. Id. at 268.

261. Id. at 269.

262. Id. at 273.

263. Id. at 276.

264. Id. at 278.

265. Defense attorneys already are "sounding the alarm" about FEHA's expanded protections. Mike McKee, Sounding the Alarm, RECORDER, June 26, 2001, at 1. One plaintiff-side attorney responded that employers were upset because they were "kicked out of pig heaven." Id. (quoting Brad Seligman). He explained that FEHA always had provided greater protection than the ADA but both state and federal courts in California ignored those differences. Id.

If FEHA's new provisions merely clarify existing law, they will apply retroactively. Id. California courts of appeal are split on the issue. Id. See also Mike McKee, Disability Rules Declared Retroactive, ReCORDER, July 26, 2001, at 1; Compare Wittkopf v. County of Los Angeles, 90 Cal. App. 4th 1205, I213 (200I) (finding that the FEHA amendinents "did not effect a radical change" in California law and therefore the new provisions did have retroactive application), with Colmenares v. Braemar 
interpreted by courts so as to closely track the language of the ADA. As Toni Cassista's case demonstrated, it was extremely difficult for fat people to gain the protection provided by FEHA's disability antidiscrimination provisions.

In Cassista v. Community Foods, Inc., ${ }^{266}$ the California Supreme Court found that obesity, when not caused by a "physiological, systemic disorder," was not a present impairment within the meaming of the statute. ${ }^{267}$ It rejected the plaintiff's perceived disability claim as well. ${ }^{268}$ The court held that it was not enough to show that the defendant made its decision based on the plaintiff's weight. ${ }^{269}$ Rather, the applicant had to show that the potential employer regarded her as "having or having had" a "physiological disease or disorder affecting one or more of the bodily systems." ${ }^{270}$ Because the court found that the plaintiff's weight was not due to a "physiological, systemic disorder," her claim failed. 271 This narrow interpretation of the "regarded as" prong of FEHA meant that perceived disability claims for weight discrimination were difficult to establish in California.

In 2000, the state legislature passed AB 2222, the Prudence Kay Popnick Act, ${ }^{272}$ amending FEHA's definition of disability in some critical ways. First, the law now explains that a person can prevail on a "regarded as" claim if she is "regarded or treated" as having or having had a condition that "makes achievement of a major life activity more difficult." 273 Whereas previously plaintiffs had to establish how their employers perceived or regarded them, which is difficult to demonstrate, under the recent amendments they only need to show that they were treated improperly. For example, Toni Cassista was unable to establish that the employer regarded her as limited in a major life activity. ${ }^{274}$ However, under the new law it would have been sufficient to show that the employer did not hire her

Country Club, Inc., 89 Cal. App. 4th 778, 778 (2001) review granted 29 P.3d 797 (Cal. 2001) (holding that the FEHA amendments "substantially change" existing law and therefore should not apply retroactively).

266. 856 P.2d 1143 (Cal. 1993).

267. Id. at 1153 .

268. Id. at 1154 .

269. Id. at 1153 .

270. Id.

271. Id. at 1154 .

272. 2000 Cal. Legis. Serv. Ch. 1049 \& (West).

273. Id. § 5 (amending CAL. Gov'T CODE $\S 12926(\mathrm{k})(4)$ (1992)).

274. See Cassista v. Community Foods, Inc., 856 P.2d I 143, 1153-54 (Cal. 1993); see also supra notes 266-271 and accompanying text. $A B 2222$ states explicitly that working is a major life activity. Id. $\S 5$ (amending CAL. Gov'T CODE $\S 12926(\mathrm{k})(1)(\mathrm{B})($ iii) (1992)). This clarification is significant since the U.S. Supreme Court has hinted that working might not be a "major life activity." Sutton v. United Airlines, Inc., 527 U.S. 471 (1999) (stating that the Court would assume "without deciding that working [was] a major life activity"). 
because of her weight. By allowing courts to infer intent from treatment, this change significantly reduces the burden on plaintiffs.

The second significant change to FEHA brought about by AB 2222 is that to proceed on a disability claim a plaintiff now is required only to show that the impairment limits, rather than substantially limits, a major life activity. ${ }^{275}$ The legislative findings for the bill specifically state that despite the interpretation put forth by the Cassista court, the legislature intended for a plaintiff to show only that the condition limits (rather than substantially limits) a major life activity. ${ }^{276}$ "Limited in a inajor life activity" under AB 2222 means a condition that makes achievement of a major life activity difficult. Since the law specifically defines working as a major life activity, ${ }^{277}$ in order to qualify for protection a plaintiff would need to show only that the employer regarded her as having a condition that made working more difficult. The law further provides that it intends to protect people who are mistakenly believed to have a physical condition that so limits their activities. ${ }^{278}$

The third important change brought about by AB 2222 is that it recognizes a discrimination claim where an employer regards or treats einployees as having a condition that might impair them in the future. ${ }^{279}$ Certain conditions, like high blood pressure, usually do not presently affect an employee's ability to work. Nevertheless, an einployer might perceive someone with high blood pressure as a risk in the future and make hiring or termination decisions on that basis (for example, firing the worker in question because of her blood pressure). ${ }^{280}$ The amended statute protects employees and potential employees against this type of action. Similarly, an employer might view a fat worker as someone who would have medical problems in the future. If a fat person was not hired because of an employer's fears about future conditions, she could pursue a discrimination action under the annended FEHA.

The fourth change is that $\mathrm{AB} 2222$ explicitly covers "medical conditions," which are defined as either health impairments related to cancer (or a history or record of cancer) or genetic characteristics. ${ }^{281}$ For the purposes of protecting people from weight discrimination, the definition of genetic characteristics is important. The statute outlines four methods of showing that one has a covered genetic trait. Two are focused on

275. Id. $\S 5$ (amending CAL. Gov'T CODE $§ 12926(\mathrm{k})(1)(B)(1992))$.

276. Id. $\$ 5$ (amending CAL. Gov'T CODE $\$ 12926(\mathrm{k})(1)(\mathrm{B})(\mathrm{ii})(1992)$ ).

277. Id. $\$ 4$ (amending CAL. Gov'T CODE $\$ 12926(\mathrm{k})(1)(\mathrm{B})$ (iii) (1992)).

278. Id.

279. Id. $\S 5$ (amending CAL. Gov'T CoDE $\S 12926$ (k)(5) (1992)).

280. An employee who suffers discrimination based on high blood pressure also might claim discrimination based on present impairment under FEHA because she likely could show that the condition made a major life activity more difficult.

281. Id. $§ 5$ (amending CAL. Gov'T CODE $\$ 12926$ (h)(1)-(2) (1992)). 
chromosomes and genes, while the other two use the broader term "inherited characteristics."282 Under each pair, there is a focus both on present risk of disease or disorder and on increased future risk. ${ }^{283}$ Each of these methods for demonstrating genetic characteristics (and thereby establishing that FEHA protection applies) provides additional avenues for fat people to establish that they have been illegally discriminated against on the basis of disability. Since there is some evidence that weight is influenced by genetic factors, ${ }^{284}$ a fat plaintiff might use such medical evidence to establish that she is in the FEHA protected class.

These FEHA amendments mean that someone like Toni Cassista should prevail on a perceived disability claim today, provided that she could demonstrate that the defendant treated her as if she had a condition that made working more difficult. Alternatively, she could show that the defendant treated her as if she had a genetic or inherited condition that might become disabling in the future. Making either showing is considerably easier than proving that the defendant perceived her as having an intpairment that limited a major life activity. This definitional change might also address some of the political objections to using a perceived disability framework. Rather than suggesting that people who are fat are unable to perform certain tasks, $A B 2222$ recognizes that there is a perception that fat people are limited in their ability to perform certain major life activities or that they are at future risk for developing medical conditions. Therefore, AB 2222 provides an important tool for people in California who are discriminated against because of their weight.

\section{B. Antidiscrimination Laws That Protect Selected Groups: Bringing} Claims Under Disparate Treatment or Disparate Impact Theories

While obtaining protection for fat people under the disability antidiscrimination laws might be difficult outside of California and a few additional states, there are a number of other possible approaches. One that is worth considering is based on the fact that being fat is more prevalent among women, people of color, and poor people.

Studies have shown racial differences among women who are fat. For example, $45.1 \%$ of black women are considered overweight, as compared to $24.6 \%$ of white women. ${ }^{285}$ Mexican-American and Puerto

282. Id. $\S 5$ (amending CAL. Gov'T CODE $\S 12926$ (h)(2)(A)-(B) (1992)).

283. Id. $\S 5$ (amending CAL. Gov'T CODE $\S 12926$ (h)(2)(A)-(B) (1992)).

284. See supra note 68.

285. Williamson, supra note 6 , at 647 . The author defines overweight as a $27.8 \mathrm{BMI}$ or more in men and a $27.3 \mathrm{BMI}$ or more in women. Id. at 646. As with insurance tables, the standard against which these women are being compared is set by white women and therefore already starts from a point of cultural bias. 
Rican-American women are found to be overweight at a rate fifteen percentage points greater than white women. ${ }^{286}$

Poverty also correlates with fatness. For "non-Hispanic" white women, rates of being overweight were $39 \%$ for women below the poverty line as compared with $25 \%$ for women above the poverty line. ${ }^{287}$ For Mexican-American women, the corresponding numbers were $46 \%$ and $40 \%$ respectively. ${ }^{288}$ Furthermore, some studies have found that "the most affluent Americans have the lowest percentage of members who are fat." 289

To the extent that federal and state antidiscrimination laws provide protection to women and people of color, fat people might obtain protection through this link. For example, if an employer policy limited jobs to people below a certain weight, a plaintiff might challenge the seemingly neutral job requirements under a disparate impact theory based on sex or race. ${ }^{290}$

The plaintiffs in Murray v. John D. Archbold Memorial Hospital, Inc. ${ }^{291}$ attempted to use such a strategy. In this case, the plaintiffs were female African-American job applicants who were not hired because of their weight. ${ }^{292}$ They complained that the defendant's weight policy had a disparate impact on "black female applicants."293 Murray failed to allege her disparate impact claim in her first EEOC charge. ${ }^{294}$ When she filed a second charge stating that defendant's weight policy had a disparate impact on African-American applicants "because black people are more likely to be thirty percent over their ideal body weight," the EEOC dismissed the charge as untimely. ${ }^{295}$ Simce the court found that the second charge alleging disparate impact was not sufficiently like or related to the first charge alleging disparate treatinent race discrimination, the court dismissed the disparate impact claim for failure to exhaust administrative procedures. ${ }^{296}$ Because the court never reached the merits of the claim, it is not clear whether this type of action would be successful or what a plaintiff would have to demonstrate to prevail. Nevertheless, it may be a promising legal

286. Id. at 647 .

287. Shiriki Kumanyika, Special Issues Regarding Obesity in Minority Populations, 119 ANNALs OF INTERNAL MED. 650, 650 (1993).

288. Id.

289. Vivian F. Mayer, The Questions People Ask, in Shadow on A Tightrope, supra note 6, at 23,28 .

290. McDermott, supra note 6, at 201. As discussed supra in Part III.B.1.d., disparate impact theory presents a number of difficulties, yet it may still be worth exploring.

291. 50 F. Supp. 2 d 1368 (M.D. Ga. 1999).

292. Id. at 1370 .

293. Id. at 1371-72.

294. Id. at 1374 .

295. Id.

296. Id. at 1381-82. Filing a charge with the EEOC is a prerequisite to bringing suit under the statute. 42 U.S.C. $\$ 2000 \mathrm{e}-5$. 
angle for a fat woman of color who has experienced weight-based employment discrimination. ${ }^{297}$

To the extent that women are held to different standards than men with regard to weight, a plaintiff also might bring a disparate treatment case based on sex. For example, in the case of flight attendants, one airline required females to weigh fourteen to twenty-five pounds less than males of the same height and age. ${ }^{298}$ Similarly, in a case involving a female teacher who was fired because of her weight, a New York court noted that no male teacher had ever been denied an appointment because of being "overweight." The court went on to state that because the standard being applied was not related to ability to perform, it had become an "aesthetic standard."299 Thus, using existing legal protections froin race and sex discrimination might prove useful to fat people who fall within one of these protected categories and are discriminated against based on their weight.

\section{State and Local Ordinances That Prohibit Weight Discrimination}

A more straightforward approach to combating weight discrimination is to prohibit it through state or local antidiscrimination laws. Only three jurisdictions in the United States provide explicit statutory protection for weight discrimination: the State of Michigan and the cities of Santa Cruz and San Francisco, California. ${ }^{300}$ The following Part will describe the ordinances and the differences between them.

297. Since Title VII does not provide protection for people who have been discriminatcd against based on socioeconomic class, this theory will be unavailing for poor women who are more likely to be fat. Nevertheless, some state or local statutes might provide protection from this type of discrimination; if so, a poor person could attempt to use the information about weight differentials among classes to bring a disparate impact claim. For example, the D.C. Code protects people from discrimination bascd on "source of income, and place of residence," which might be viewed as an attempt to protect poor people who are receiving government assistance and thereby protect people from discrimination based on socioeconomic class. See D.C. CodE ANN. $\S$ I-250I (2001).

298. Frank v. United Airlines, Inc., 2I6 F.3d 845, 848 (9th Cir. 2000), cert. denied, 121 S. Ct. 1247 (200I) (holding that the airline's policy for flight attendants violated Title VII); see also Pamela Whitesides, Flight Attendant Weight Policies: A Title VII Wrong Without a Remedy, 64 S. CAL. L. REV. I75, 197-99 (1990) (discussing sexism in the airlines' treatment of flight attendants especially with regard to differential weight standards and arguing that weight standards in the industry are also used to discriminate against older workers).

299. Parolisi v. Bd. of Exam'rs of New York, 285 N.Y.S.2d 936, 940 (N.Y. Sup. Ct. 1967).

300. New York and Texas rejected measures similar to Michigan's Elliott-Larsen Act. See Petersen, supra note 8, at 112 . In addition, the District of Columbia provides general protection against appearance discrimination. Chapter 25 of the D.C. Code prohibits discrimination based on any characteristic other than personal merit, "including, but not limited to . . race, color, religion, national origin, sex, age, marital status, personal appearance, sexual orientation, familial status, family responsibilities, matriculation, political affiliation, disability, source of income, and place of residence or business." D.C. CODE ANN. $\$ 2-1401.01$ (2001). By "personal appearance," the ordinance means "the outward appearance of any person . . . with regard to bodily condition or characteristics, manner or style of dress, and the manner or style of personal grooming. ..."Id. § 2-1401.02. The ordinance provides, however, that employers still may require "cleanliness, uniforms, or prescribed standards" so long as they are applied uniformly to a class of employees and are "for a reasonable business purpose," 


\section{Michigan}

In 1975 the state of Michigan added weight and height to the list of attributes protected by its Elliot-Larson Civil Rights Act. ${ }^{301}$ The Act covers discrimination based on "race, color, religion, national origin, age, sex, height, weight, familial status, or marital status." ${ }^{302}$ 1t allows an exception where employers can establish a bona fide occupational qualification. ${ }^{303}$ In analyzing cases under the Act, the Michigan state courts have adopted the federal burden-shifting analysis framework from McDonnell Douglas Corp. v. Green..$^{304}$

Michigan's Ombudsman commented that one reason height and weight were added to the law was that "certain height and weight characteristics tend to be linked to certain ethnic groups or to women." ${ }^{305} \mathrm{He}$ went on to note that only eight to ten cases of weight-related discrimination had been pursued to the Civil Rights Commission since the law was passed. ${ }^{306}$ He further stated that for the most part einployers had not objected to the

or where style or manner of grooming would present a "danger to the heath, welfare, or safety of any individual." Id. There are no reported cases in which the D.C. ordinance was used to attack weightbased discrimination, although this type of bias certainly should fall within the statute's coverage. See also Donald L. Bierman, Jr., Comment, Employment Discrimination Against Ovenveight Individuals: Should Obesity Be a Protected Classification?, 30 SANTA ClARA L. Rev. 951,960 (1990) (stating that the D.C. ordinance has not been used specifically to protect against weight-based discrimination).

While appearance discrimination is closely related to weight discrimination, this Comment focuses more narrowly on weight-related issues. For interesting reading on appearance discrimination, see, for example, Note, Facial Discrimination: Extending Handicap Law to Employment Discrimination on the Basis of Physical Appearance, 100 HARv. L. REv. 2035, 2035, 2049 (1987) (arguing that appearance should not be the basis for employment decisions and that employers should move away from using inperson interviews to make hiring decisions); see also Adamitis, supra note 119.

301. SolovaY, supra note 13 , at 245.

302. Mich. CoMp. Laws ANN. $\$ 37.2202$ (1)(a) (West Supp. 2001).

303. Id. $\$ 37.2208$.

304. Bymes v. Frito-Lay, Inc., 811 F. Supp. 286, 291 (E.D. Mich. 1993) (citing Dubey v. Stroh Brewery Co., 462 N.W.2d 758 (Mich. Ct. App. 1990), as an example of this type of burden-shifting). McDonnell Douglas Corp. v. Green, 411 U.S. 792 (1973), established the order of proof in Title VII disparate treatment cases. The plaintiff must establish a prima facie case of discrimination. $I d$. at 802. Then the burden shifts to the defendant to present a legitimate non-discriminatory reason ("LNDR") for the adverse employment action. Id. If an LNDR is established, the plaintiff can attempt to show that it is a pretext for a discriminatory motive. Id. at 804. In Texas Department of Community Affairs $v$. Burdine, 450 U.S. 248 (1981), the Court clarified that the plaimtiff "retains the burden of persuasion." Id. at 256. Once the defendant offers an LNDR, the plaintiff can atteunpt to show that the LNDR was not the "true reason" for the employment decision. Id. She might succeed in establishing pretext "either directly by persuading the court that a discriminatory reason more likely motivated the einployer or indirectly by showing that the employer's proffered explanation is unworthy of credence." Id.

305. SolovaY, supra note 13 , at 245 .

306. Id. One article stated that in the first year after the law's enactment, two weightdiscrimination claims were filed against the same defendant. Both claims were resolved through consent orders with the Civil Rights Commission. Jane Osborme Baker, The Rehabilitation Act of 1973: Protection for Victims of Weight Discrimination?, 29 UCLA L. Rev. 947, 970 (1982). Another article stated that between 1976 and 1981, 91 weight discrimination complaints were filed. Mason, supra note 86 , at $354 \mathrm{n} .98$. 
law. ${ }^{307}$ The legal protections provided by the act have led to a number of settlements and to employers revising discriminatory employment policies. ${ }^{308}$

The following cases brought under Michigan's Civil Rights Act illustrate the ways courts have applied the Act to weight discrimination claims. In Lamoria v. Health Care \& Retirement Corp.,$^{309}$ an appellate court found that the plaintiff had stated a claim for weight discrimination under the Act. ${ }^{310}$ Lamoria was a registered nurse at a retirement facility who stood 5 feet 7 inches tall and weighed 240 pounds. ${ }^{311}$ Her new supervisor indicated her intent to terminate people that she perceived as overweight. ${ }^{312}$ The plaintiff was fired while out on medical leave for a work-related knee injury. The trial court found that the plaintiff was not qualified for her job due to her injury and held that she failed to establish a prima facie case..$^{313}$

The Michigan Court of Appeals found that the trial court improperly applied the McDonnell Douglas framework because the plaintiff had presented "direct evidence of discriminatory animus by a decisionmaker." 314 It further stated, in adopting federal mixed-motive case law, that such direct evidence usually precludes summary judgment. ${ }^{315}$ Addressing the substance of the case, the court found it improper to require a worker who was out on medical leave to show that she was physically qualified for the position at the time of termination. ${ }^{316}$

307. Solovay, supra note 13 , at 245.

308. Adamitis, supra note 119, at 210.

309. 584 N.W.2d 589 (Mich. Ct. App. 1998), aff'd in relevant part by 593 N.W.2d 699, 701 (Mich. Ct. App. 1999).

310. Id. at 595.

311. Id. at 589.

312. Id. at 590 .

313. Id. at 592.

314. Id. at 593. In Price Waterhouse v. Hopkins, 490 U.S. 228 (1989), the Supreme Court established an alternative to the McDonnell Douglas pretext model, called mixed-motive theory. In the 1991 amendments to the Civil Rights Act, Congress codified parts of Price Waterhouse and imposed liability when a plaintiff can show discrimination is a "motivating factor." 42 U.S.C. $\$ 2000 \mathrm{e}-2(\mathrm{~m})$. There is a split in the circuits about what type of "direct evidence" a plaintiff must present in order to proceed on a mixed-motive theory. For example, some courts have allowed "good" circumstantial evidence to trigger the mixed-motive analysis. See, e.g., Thomas v. National Football League, 131 F.3d 198, 204 (D.C. Cir. 1997) (finding that direct evidence includes circumstantial evidence as long as it actually relates "to the question of discrimination in the purticular employment decision" rather than "potentially unrelated forms of discrimination in the workplace"). Other courts have required a close connection between the evidence and the decision in question. See, e.g., Indurante v. Local 705, Int'1 Bhd. of Teamsters, 160 F.3d 364, 367 (7th Cir. 1998) (finding that despite two decision makers' comments that they wanted to get rid of all 1talian workers, the comments were not direct evidence of national-origin discrimination because they were not made to the plaintiff, did not mention him in particular, and were made a number of months before his termination). In the California Court of Appeal, Toni Cassista's case was treated as a mixed-motives case involving direct evidence of discrimination. Cassista v. Community Foods, 10 Cal. Rptr. 2d 98, 103 (1992).

315. Lamoria, 584 N.W.2d at 593.

316. Id. at 594 . 
As to the elements needed to prove a weight discrimination claim, the court stated that no published state supreme court or appellate court opinions set forth the necessary components of such a claim. ${ }^{317}$ It went on to establish that a plaintiff could prove a weight discrimination claim by showing that her weight was a "determinative factor" in her termination. ${ }^{318}$ Turning to the facts, the court found that by showing that various decision makers had made disparaging reinarks about people who were overweight and then that a number of overweight people were terminated, the plaintiff had presented sufficient direct evidence to support her claim of weight discrimination. ${ }^{319}$ The court was careful to say, although in a footnote, that it would not consider "mere advice about diets" to rise to the necessary level of animus. ${ }^{320}$ The court concluded by reversing the trial court's decision to grant summary judgment to the defendants on the weight-discrimination claim. ${ }^{321}$ Similarly, in Ross v. Beaumont Hospital, ${ }^{322}$ the court found that the plaintiff could prevail because she showed that her weight was a determining factor in her termination despite the existence of other reasons for the adverse employment action. ${ }^{323}$

By contrast, in Byrnes v. Frito-Lay, Inc., ${ }^{324}$ Byrnes failed to establish even a prima facie case of weight discrimination. ${ }^{325}$ There, Byrnes' supervisors were constantly telling him to diet, and one said he would have to lose weight "if he wanted to go anywhere with the company." lost on sumunary judgment. ${ }^{327}$ The court found that he was not qualified for the position he held at the company at the time of his discharge. ${ }^{328}$ It went on to state that he had not offered any proof that the defendant's decision to terminate him was based "even partially" on his weight. ${ }^{329}$

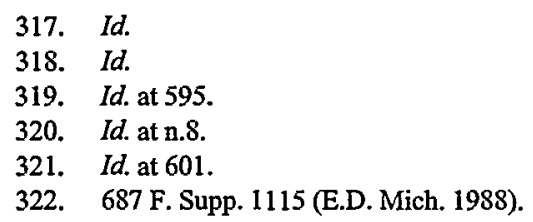

323. Id. at 1124. Ross was a physician who was narcoleptic and allegedly abusive to members of the staff. Id. at 1119-20,1120 n.19. She also was fat, and her employer told her that she had to provide a monthly letter from her physician about weight loss treatment. Id. at 1124. The jury found in her favor on her state weight discrimination claim. The court denied the defendants' request for a judgment not withstanding the verdict because the jury reasonably could have found that the plaintiff's weight was a "determining factor" in the hospital's decision to terminate her. Id. at 1125 . Nevertheless, the court ordered a new trial on the issue because the jury's verdict was "against the clear weight of the evidence." Id.

324. 811 F. Supp. 286 (E.D. Mich. 1993).

325. Id. at 291.

326. Id. at $288-89$.

327. Id. at 293.

328. Id. at 291. Bymes apparently had problems working for a female supervisor. Id. at 289 . No position with a "male boss" was available. Id.

329. Id. at 292. 
The court also considered whether Byrnes had stated a cause of action for weight-based harassment. ${ }^{330}$ Although the Michigan state courts had not yet established the requisite elements of weight harassment, the Byrnes court found it likely that they would model such a harassment claim after racial harassment claims. ${ }^{331}$ Therefore, the court reasoned, a plaintiff would have to show that there had been "repeated slurs" or other types of harassment. ${ }^{332}$ Since Byrnes alleged "at best one slur" and since the evidence of a connection between the alleged harassment and Byrnes' weight consisted of merely "speculative conclusions," the court granted the defendant's summary judgment motion. ${ }^{333}$

In Howard v. City of Southfield, ${ }^{334}$ the Sixth Circuit rejected the plaintiff's claim of weight discrimination under Michigan's Civil Rights Act. ${ }^{335}$ Howard, who weighed 300 pounds, had applied for a job as a firefighter. ${ }^{336}$ A psychologist who interviewed all the candidates determined that Howard's weight was a "physical manifestation of an inability to deal with stress." 337 Based on this diagnosis and a number of "inappropriate responses" to psychological assessment questions, Howard was not offered the job. ${ }^{338}$ The district court found that Howard did not even establish a prima facie case of weight discrimination because he failed to prove that he was eligible for the position. ${ }^{339}$

The appellate court rejected Howard's disparate treatment claim because he failed to offer evidence of intentional discrimination. ${ }^{340}$ The court found that Howard failed to establish a disparate impact claim because he presented no evidence regarding the weight of the other applicants for the job nor that of the firefighters hired. ${ }^{341}$ The court therefore affirmed the district court's grant of summary judgment to the defendant with regard to the weight-discrimination claim. ${ }^{342}$

Courts interpreting Michigan's weight antidiscrimination law have thus developed a jurisprudence that closely tracks Title VII antidiscrimination law. Specifically, the decisions have applied a McDonnell Douglas pretext-type analysis when there is no direct evidence of animus by employers. They have applied a mixed-motive analysis when employers do

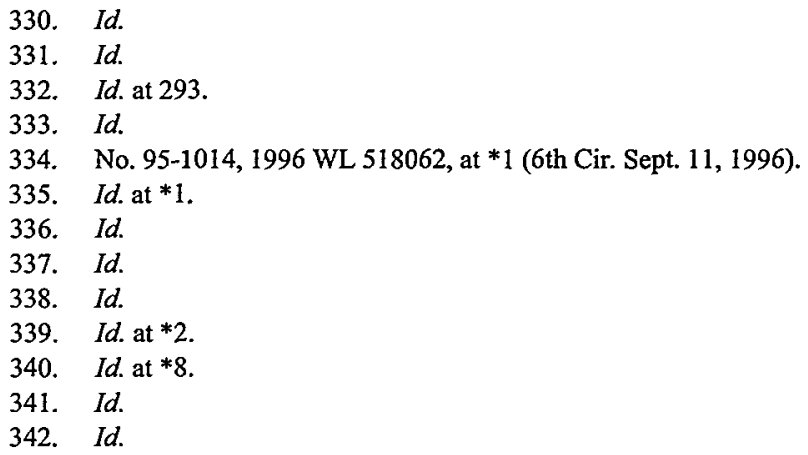


demonstrate weight-based animus. Plaintiffs have not always prevailed under the Michigan law but some have been successful. It is likely that similar laws in other states would significantly add legal protection for fat workers.

\section{California}

Two cities in California have passed local laws prohibiting weight discrimination. In 1992, Santa Cruz passed an ordinance prohibiting discrimination in employment, education, housing, and public accommodations based on "age, race, color, creed, religion, national origin, ancestry, disability, marital status, sex, gender, sexual orientation, height, weight, or physical characteristic."343 The law provides an exception for bona fide occupational qualifications. ${ }^{344} \mathrm{~A}$ violation of the law carries a fine of $\$ 103$ and clears the way to filing a civil lawsuit. ${ }^{345}$ According to the Santa Cruz City Attorney, the ordinance was "well received by the City's residents, landlords, and businesses." ${ }^{346} \mathrm{He}$ further noted that he was not aware of any private enforcement actions and that the City had not taken any "formal enforcement actions" pursuant to the ordinance. ${ }^{347}$

Recently, San Francisco joined Santa Cruz im prohibiting weight discrimination. In 1999, a fitness company placed billboards around San Francisco that read: "When the aliens come, they will eat the fat ones first." ${ }^{\text {348 }}$ This advertising campaign was so offensive to fat people in the area that they launched an effort to have the San Francisco Board of Supervisors pass an antidiscrimination law prohibiting weight discrimination. ${ }^{349}$ Their efforts paid off on May 8, 2000, when the Supervisors unanimously passed an ordinance making it illegal to discriminate based on weight and height. ${ }^{350}$ The law provides that city contractors who discriminate on the basis of weight or height could lose their contracts or be fined. ${ }^{351}$ The ordinance exempts businesses with physical requirements such as police and fire departments. ${ }^{352}$

343. Santa Cruz, Cal., Mun. Code $\$ 9.83 .010$ (1995).

344. Id. $\$ 9.83 .080(6)$.

345. Dan Reed, S.F. Weighing In on Size, SAN Jose Mercury News, Apr. 28, 2000, at 1 A.

346. Solovay, supra note 13, at 244.

347. Id.

348. Evelyn Nieves, New San Francisco Ordinance Decrees That All Sizes Fit, N.Y. TIMEs, May 9,2000 , at A20.

349. The group that began the campaign against the billboard and for the ordinance was the Fat Activist Task Force. Id. The Task Force is a "coalition of activists participating in organized campaigns to fight size discrimination." Fat Activist Task Force, at http://naafa.org/fatf. The organization was formed in 1989 in order to urge Hallmark to discontinue offensive products such as cards that make fun of fat people. Id.

350. Id. See also Nieves, supra note 348, at A20.

351. Edward Epstein, Fat People Get a Positive Hearing in S.F., S.F. CHron., May 4, 2000, at 1.

352. San Francisco Bans Discrimination by Size, Agence France Presse, May 10, 2000, at 1. 
While the ordinance was the butt of numerous jokes ${ }^{353}$ and some very hostile press reports, ${ }^{354}$ a representative of San Francisco's Human Rights Commission stated that the Commission was "convinced that [weight discrmination] is a serious problem that represents a loss of civil rights." 355 Although the ordinance clearly represents a symbolic victory, a number of people have expressed skepticism about whether the law will have any real effect. One columnist suggested that since in the past the Supervisors had voted to "protect tropical hardwoods, the Burmese people and San Francisco's two daily newspapers" to no avail, the ordmance was unlikely to make any significant change. ${ }^{356} \mathrm{On}$ a more serious note, the city attorney suggested that the ordinance would be preempted by FEHA. ${ }^{357}$ Nevertheless, the ordinance could still be effective since most of the bias complaimts brought to the city's Human Rights Commission are resolved through mediation. ${ }^{358}$

In July 2001, the San Francisco Human Rights Commission adopted compliance guidelimes to aid in enforcement of the new ordinance. ${ }^{359}$ With regard to employment discrimination, the guidelines forbid discrimmation in "recruitment, selection, hiring, wages, uniforms, hours and conditions of

353. An article in the San Jose Mercury News about the ordinance demonstrated the kind of nasty jokes that people made at the expense of fat people. The article opined that the reason fat people were overweight was that they ate too much. The supposed lunch menu of a fat person consisted of "two hoagies [a]nd a pizza." Reed, supra note 345, at 1. Cf. Rothblum, supra note 6, at 9-10 (discussing the myth that fat people eat more than thin people). A San Francisco U.S. Attomey suggested that the ordinance went too far and wondered "[w]hat next, an ordinance banning discrimination against people with congenital conditions making them ugly?" San Francisco Bars Discrimination by Size, supra note 352 , at 1 . Since "unattractive people" are not an identifiable group in the same way that fat people are, this Comment does not advocate for explicit protection against discrimination for the unattractive except to the extent such discrimination has disparate impact on other protected groups. See supra Part III.B.1.d. Other commentators have argued, however, that this type of discrimination perhaps should be prohibited. See, e.g., supra note 300 (discussing appearance discrimination).

354. See, e.g., Peter Byrne, As a Matter of Fat, SF WEEKLY, Jan. I7, 200I, at 18, 22 (arguing that fat people do not deserve legal protection, that the ordinance was passed without factual findings about the scope of the problem, and that it will be unenforceable).

355. Nieves, supra note 348, at A20.

356. Id. (quoting local columnist Rob Morse).

357. Edward Epstein, S.F. Draws Bead on Weight, Height Bias, S.F. Chron., May 9, 2000, at AI7. In Delaney v. Superior Fast Freight, 14 Cal. App. 4th 590, 596-97 (1993), the court of appeal held that a local ordinance that provided greater antidiscrimination protection than state law was preeinpted because the state legislature intended to exclude local regulation.

358. Epstein, supra note 357, at AI7. The first complaint brought under the new ordinance involved an 8 year-old girl who was denied admission to the San Francisco Ballet School because she was the "wrong body type" for a ballet dancer. The complaint also alleged sex discrimination, saying that the school enforced its height and weight standards more stringently against girls than boys. Edward Epstein, Girl Fights for a Chance to Dance, S.F. CHRoN., Dec. 7, 2000, at AI. This case has drawn national attention with stories in magazines ranging from People to The New Yorker. Michelle Tauber, Dancer's Image, PeOple, Mar. 5, 200I, at 79-80; A Ballerina Body, THE New YoRKer, Mar. $5,200 \mathrm{I}$, at 38 .

359. San Francisco, Cal., Compliance Guidelines to Prohibit Weight and Height Discrimination (July 26, 2001). 
employment, promotion, training, development, or benefits." ${ }^{" 360}$ The guidelines specifically state that employers may not exclude workers from front office positions based on concerns about a "professional appearance.",361 Verbal or written harassment also is prohibited. ${ }^{362}$ Employers must make "readily achievable modifications" to their workplaces such as "accessible furnishings, workplace layout, and equipment" as well as ensure that common areas "are accessible to people of all sizes." 363 Thus, the San Francisco ordinance is being implemented through detailed guidelines that both educate about weight discrimination and enforce the city's prohibition against weight discrimination.

Working for local ordinances prohibiting weight discrimination, like those in Santa Cruz and San Francisco, appears to be a goal of the National Association to Advance Fat Acceptance ("NAAFA"). NAAFA is hoping to have height and weight included as protected categories in existing antidiscrimination laws nationwide. ${ }^{364}$ Pursuing local ordinances may be an efective way to combat this form of employment discrimination. Linda Krieger suggests that such local laws are a good tool for establishing protection for stigmatized groups. ${ }^{365}$ She focuses on three aspects of the Santa Cruz ordinance that led to its local acceptance and effectiveness. ${ }^{366}$ First, the ordinance applied only to a small and relatively insular jurisdiction. ${ }^{367}$ Despite the fact that the national media had a field day poking fun at the measure, ${ }^{368}$ the cominunity that adopted the ordinance was the one "empowered to interpret and apply it." ${ }^{369}$ Second, the law's primary enforcement measure is mediation rather than litigation. ${ }^{370}$ Therefore, potentially unsympathetic judges are not the actors "infusing" the law with meaning. ${ }^{371}$ Third, the ordinance was subject to a full debate and revisions that solidified its

360. Id. $\S$ V.A. The guidelines note that weight and height may be used as employment criteria if weight or height is a bona fide occupational qualification ("BFOQ"). The employer bears the burden of demonstrating a BFOQ. Id. § V.C.

361. Id. The guidelines also caution against discriminating against workers based on the physical distribution of their weight, saying that it is "impermissible to reject a candidate because she carries her weight around her abdomen, in favor of a candidate of the same weight and height who is differently proportioned." Id. \& V.A.

362. Id. $\S$ V.B. For example, the guidelines disapprove of a hypothetical workplace poster with the slogan "No Fat Cops," saying that it is instead appropriate to "advocate increased health and fitness for people of all sizes." Id.

363. Id. § V.D.

364. Cynthia Hubert, San Francisco Says Size Discrimination Must End, SCRIPPS Howard NEws SERVICE, May 9, 2000, at 1 .

365. Linda Hamilton Krieger, Afterword: Socio-Legal Backlash, 21 Berkeley J. EMPL. \& LAB. L. $476,498-503$ (2000).

366. Id. at $499-500$.

367. Id. at 501 .

368. Id. at 498-99.

369. Id. at 501 .

370. Id. at 502.

371. Id. 
reflection of an underlying social norm that one should not "judge a book by its cover." 372 These features are essentially impossible to achieve at a national level. Although national antidiscrimination laws are powerful in scope, they may be severely limited in their application by legal decision makers unsympathetic to the goals of the statute. ${ }^{373}$ Therefore, local and state laws directed at eliminating weight discrimination may be more useful than a national approach because such laws provide greater opportunities for consensus building. Furthermore, once they are on the books, locally based decision makers will be providing legal enforcement. Finally, educating about weight discrimination may be more effective on the state and local levels.

\section{CONCLUSION}

Discrimination is socially and economically harmful. It deprives workers of valuable employment and employers of a pool of qualified employees. It also creates divisions in society that are harmful to our community and long term social stability. Furthermore, it prevents individuals from developing their full potential.

Fat people are a group that has been discriminated against in employment and marginalized in society. The fact that fat people are being judged on their appearance rather than on their merits is simply unfair. A solely fairness-based approach, however, may not provide any limiting principle for who should be included within antidiscrimination laws. An equalitybased theory recognizes that it is most important to provide legal protection to groups who have been stigmatized and oppressed. Antidiscrimination laws should be based both on fairness and on equality and fat people should be protected under this approach.

Assuming that fat people deserve legal protection, it is important to consider what tools are already available to provide legal remedies for weight discrimination. While legal strategies that invoke federal disability antidiscrimination laws have sometimes been successful, those laws ultimately do not provide the best protection against weight discrimination. State disability antidiscrimination laws, especially AB 2222 in California, are much more promising vehicles to vindicate weight discrimination. California law now effectively recognizes that groups that are stigmatized on the basis of physical appearance should be protected under disability laws. Fat workers should be aware of the changes to FEHA that make weight discrimination claims much more likely to succeed. Another available strategy under existing laws might focus on the link between weight and other protected categories such as sex and race. Such an approach

372. Id. at 502-03.

373. See id. at 501-03. 
could utilize either disparate treatment or disparate impact theory to address weight discrimination.

One final method of addressing this issue would be to pass weight antidiscrimination ordinances at the local and state levels. Gaining approval of such measures provides the dual benefits of educating people about fat oppression and enhancing the laws' effectiveness. Such laws should, if possible, contain provisions for alternative dispute resolution such as mediation. While a national law prohibiting weight discrimination may be desirable, it is unlikely to pass and might be limited by judicial interpretation hostile to the group protected. Therefore, it will be more productive to focus instead on passing new ordinances in smaller commumities and attempting to fully utilize existing laws. 
